\title{
Osmotic Mobilization and Union Support during the "Long Protest Wave"
}

\begin{abstract}
Despite increasing interest in the impact of social movements that target private firms, we know little about the emergence of such movements. Social movement theory situates such emergence in the context of larger protest cycles but has not tested the idea. We theorize about the determinants of osmotic mobilization - social movement spillover that crosses the boundary of the firm - and how it should vary with the ideological overlap of the relevant actors and the opportunity structure that potential activists face inside the firm. We test our hypotheses by examining the relationship between levels of protest in American cities around issues like Civil Rights, the Vietnam War, and the women's movement; and subsequent support for labor-union organizing in those cities. We combine nationally representative data on protest events from 1960 to 1995 with data on every union-representation election held from 1965 to 1999 . We find that greater levels of (lagged) protest activity are associated with greater union support; that such osmotic mobilization is greater when there is substantive overlap between the claims of the two parties; and that the extent of mobilization varies with the opportunity structure within private firms. We discuss the implications of ideological and interest overlap as a contingent factor in future research on the emergence of mobilization targeting private firms.
\end{abstract}

\section{Introduction}

Research on how social movements affect firms has grown over the last fifteen years (King \& Pearce (2010), Soule (2012), Soule (2013), Soule \& King (2015), and Briscoe \& Gupta (2016) all review this work). We know that social movement activism affects firms' financial performance (Epstein \& Schnietz 2002, King \& Soule 2007, Bartley \& Child 2011), their images, and their reputations (Bartley \& Child 2011, Vasi \& King 2012). We also know that firms often respond to activist demands with varying mixtures of concrete (King 2008, Briscoe \& Safford 2008, Soule, Swaminathan \& Tihanyi 2014) and symbolic concessions (McDonnell \& King 2013). It is not surprising that organizational scholars have focused so much attention on how movements affect firms, given that this stream of research emerged roughly when social movement scholars had shifted attention from studying the antecedents of mobilization toward studying how movements influence their targets (Snow \& Soule 2010). And of course, it is important to understand how movements 
affect firms. Until recently, though, organizational scholars have not studied the factors influencing the emergence of mobilization against firms (McDonnell, King \& Soule 2015).

The broader literature on the emergence of activism emphasizes factors such as societal changes that give people more time and resources, shifts in the opportunity structures that make mobilization seem worthwhile, the absolute and relative sense of deprivation felt by individuals, the emergence of framings that resonate with individuals' world views, and crises or suddenly imposed grievances that may galvanize people into action (see reviews in Snow \& Soule (2010) and chapters in Snow, Soule \& Kriesi (2004)). Within this broad tradition, a smaller stream specifically looks at mobilization within organizations, and asks when we are likely to find incumbents mobilizing for change within their organization (Hirschman 1970, Zald \& Berger 1978, Soule 2009, Briscoe \& Gupta 2016). Some of this work examines how the claims of movements change (Ansari, Fiss \& Zajac 2010), and particularly how activists moderate their claims, when contention shifts inside the firm (van Wijk, Stam, Elfring, Zietsma \& den Hond 2013). All such work acknowledges that external political and social changes are probably paramount for understanding when intra-organizational mobilization occurs, but "only a small body of research has examined...indirect effects of activism on further mobilization in organizational settings" (Briscoe \& Gupta 2016, p. 700).

A clearer understanding of the link between extra-organizational and intra-organizational social movement activism is important both for social movement and organizational research. While they do not present an empirical test of the claim, Zald \& Berger (1978, p. 825) discuss how organizations are sites for working out broader political and social issues. As such, "Organizations are webbed by the larger society":

More particularly, since the society may enjoin authorities within organizations from punitive actions or require the organizations to permit or even encourage group formation, the constraints imposed by the larger society may provide a powerful stimulus for social movement formation (p. 831).

If extra-organizational mobilization is an important precursor to intra-organizational mobilization, then an obvious jumping-off point for studying the emergence of mobilization within firms is to situate such mobilizations in the context of larger protest cycles (Snow \& Benford 1992). The "early risers" in a social movement make claims on elites that "easy riders" can follow up on (Tarrow 1989). They can expose weaknesses, such as unforeseen divisions among potential targets, 
that followers can exploit, and they can alter the "master frames" of contention and advocacy that later movements utilize (Tarrow 2011). Mass movements should alter the opportunity structures that future potential mobilizations face. And if broader social and political issues are often worked out in organizations, then we should expect greater intra-organizational mobilization in the wake of large social protest cycles.

We take these ideas as a starting point, and elaborate several tests of the claim. For our tests, we examine the impact of public protests around issues such as Civil Rights, the Vietnam War, and the women's movement on workers' support for organizing new labor unions between 1965 and 2000. This is a substantively important setting in which to explore this question. The protest cycle that began with the Civil Rights movement was arguably the largest in the history of the United States. The Civil Rights movement fed into related and sometimes competing mobilizations against the Vietnam War and in favor of women's rights; the mobilizations of the 1960s in turn echoed in the environmental movement, the anti-nuclear movement, and beyond. Even today, it is common for a new spate of protest to be compared to the "long protest wave" of the 1960s. Meanwhile, for more than half a century, from the Great Depression through the 1980s, labor unions were the archetypical vehicle for working-class mobilization. They had real power to influence policies in many companies (Slichter, Healy \& Livernash 1960, Kochan, Katz \& McKersie 1986, Edelman 1990). Unions were themselves the organizational product of an earlier wave of social movement activism (Lewis 2013). And while long-established unions have been criticized as too bureaucratic or captured by the logic of the organizations they are meant to challenge (Fantasia \& Voss 2004, Taylor 2007), both labormovement researchers and social-movement scholars agree that "Winning union recognition and the legitimation of strikes is part of a social movement process in society and in specific organizations" (Zald \& Berger 1978, p. 842). It would be useful to understand patterns of influence between the long protest wave and organized labor, not least because that relationship has historically been fraught, and influences much thinking in social movement, labor movement, and organizational research (Levy 1994, Voss \& Sherman 2000, Clawson 2003).

This setting is also theoretically fruitful. It may be non-controversial to say that social movements produce successors (McAdam 1995), but there is almost no research on why we would expect some types of successors and not others. When is there more likely to be spillover from outsider activity to insider mobilization (Briscoe \& Gupta 2016)? It seems likely, and we theorize, that such 
spillover is more likely when there is substantive overlap between claims made by activists earlier in the protest cycle and the claims of later, intra-organizational activists. We also theorize that the magnitude of such spillover should vary with "the constraints imposed by the larger society" on organizations (Zald \& Berger 1978). An advantage in considering the American labor movement here is that its constituent unions have varied considerably in their stance toward issues like equal opportunity, immigration, and U.S. foreign policy, issues that motivated many people during the long protest wave. The organizing climate for unions also changed in these years, as the national political climate moved sharply against organized labor. This means we can examine both whether spillover varied by substantive overlap and with changes in the opportunity structure.

We combine protest data from the Dynamics of Collective Action Project with data on all private-sector union organizing drives in the United States to explore the lagged effect of protest in a metropolitan area on the votes that private-sector unions received in elections in that area. Because there were more than 20,000 protest events and more than 150,000 organizing drives during the period we consider, we can explore and control for variation over time, across space, and among the different protest events and unions involved. Because we work with event-level rather than aggregated data, we can explore how spillover varies by the types of claims made by social movements and by the reputations of the unions. We find positive spillover from protest activity to worker support for labor unions. This spillover accrued disproportionately to unions with more "progressive" track records on issues like civil rights, opposition to the Vietnam War, or immigration. Furthermore, these effects were disproportionately large in the wake of mobilization around employment-related causes, and shrank in the wake of conservative political reaction that limited the external protesters', labor movement's, or both's room for maneuver.

Those shifts in the political opportunity structure help explain why the spillover we find was not sufficient to reverse the overall decline of organized labor in the United States over the last generation. The spillover that we do find, though, jibes with more recent arguments that the relationship between the New Left and labor was not as confrontational as once supposed (Levy 1994, Nelson 2001). Our results also speak more broadly to how we might continue to explore the emergence of mobilization against firms. The channels through which protests influence formal organizations is a vibrant area of organizational research (King \& Pearce 2010). Research on tactics like boycotts (McDonnell \& King 2013), shareholder resolutions (Model, Soule \& King 2016, 
McDonnell, King \& Soule 2015), and divestment campaigns (Soule 2009, Soule, Swaminathan \& Tihanyi 2014) have all wrestled with the role that contentious politics outside the firm plays in mobilizing insiders in favor of reform policies (see also Briscoe \& Safford (2008)). The idea that agreement on the substance of activists' claims drives collaboration has been bruited in such work, but because most such studies have focused on a single issue campaign, variance on this dimension has been hard to test. Exploring variance requires either information on social movement industries or variation on organizations within such an industry. While disaggregated data on social-movement activity like we use here is quite rare in historical settings, it is quite common today. Contemporary social mobilization leaves digital traces in real time; furthermore, we can often observe the individual as well as the organizational links between social movements, which gives us yet more scope for understanding the specific mechanisms that produce different types of spillover. Thus while our analyses here are useful for generating and testing theory, we close by discussing how the promise of this research is for the contemporary and ultimately perhaps predictive study of mobilization around and within organizations.

\section{From mass movements to private contention: osmotic mobilization}

Social movement research has long been interested in the dynamics of interaction among different movements (e.g., McCarthy \& Zald (1977), Zald \& McCarthy (1980)). Social movement organizations share personnel and office space (Cress \& Snow 2000), form coalitions (Van Dyke \& McCammon 2010), and learn tactics from one another (Wang \& Soule 2012). They also compete with one another in scarce resource environments (Olzak \& Uhrig 2001, Olzak \& Ryo 2007, Soule \& King 2008, Larson \& Soule 2009). These different channels of influence, both cooperative and competitive, comprise "spillover" between different movements and movement organizations (Soule 2004, Whittier 2004). ${ }^{1}$

Research on spillover between movements has not yet been embraced by organization scholars interested in how social movements affect firms. This is important because we often presume that activism targeting firms has its roots in broader social movements, but we know little about the interaction between movements outside of firms, and movements within firms (Soule 2009, Vasi

\footnotetext{
${ }^{1}$ See also Levy's (1994) and Miller's (1987) accounts of mentorship of the New Left by the Old in the early 1960 s.
} 
\& King 2012, Briscoe \& Gupta 2016, Model, Soule \& King 2016). We focus here on a specific form of movement spillover, which we refer to as "osmotic mobilization." Osmotic mobilization is simply the spillover of activism across an organizational boundary, from activism in the streets to activism within a firm. We invoke "osmosis" here because we are interested in how outsiderto-insider spillover varies. The chemical process of osmosis varies by osmotic pressure, which is determined by the properties of the solutions on either side of a boundary. What properties of extra- and intra-organizational actors will affect the rate of osmotic mobilization?

The idea that mobilization within a firm has roots in mass mobilization outside the firms draws on work on protest cycles (Snow \& Benford 1992, Tilly 1998, Tarrow 2011). "Successful" protest usually involves disruption of the social order as well as less contentious actions like influence and negotiation. While the origins of individual grievances may be specific to organizations, those individuals' dependence on those organizations means they have less latitude to protest (Hirschman 1970). Furthermore, people are prone to interpret their personal experiences as idiosyncratic, rather than reflecting broader structural inequalities (Mills 1967). It is through the comparison of grievances across individuals, organizations, and walks of life that such grievances are usually reframed as a problem of the "system" that needs reforming (Snow \& Benford 1992). Thus protest cycles frequently begin with mass mobilizations, but those mobilizations in turn open up new space for successor movements (Tarrow 1989) The "early riser" mobilizations can normalize diagnoses of and claims against the status quo that would previously have sounded extremist (e.g., Haines (1984)). Such effects have been demonstrated in the case of single social movements (Dobbin 2009, Rojas 2010); here we extend the basic logic to spillover mobilization around different claims, and argue that greater levels of extra organizational social mobilization will encourage and inspire group mobilization within organizations via osmotic mobilization.

On top of this, however, we argue that osmotic pressure will be greater when there are actors in an organization who have access to resources, including knowledge. Continuing the logic of research on protest cycles, while initial mobilization can alter norms and make once-radical claims seem more feasible, that same mobilization often lacks the detailed knowledge of existing organizations that can help translate general claims into specific reforms (Briscoe \& Gupta 2016). New movements with insider knowledge of potential targets would be among the best placed to capitalize on openings created by earlier mobilization. Thus we argue that osmotic mobilization will be greater for groups 
that have the ability to advance the earlier claims.

While resources and abilities are important, we do not want to assume that spillover is simply the content-neutral transfer of tactics or routines between organizations (Wang \& Soule 2012). Overlap and sympathy in claims also matters. We argue this because many of the channels of spillover that prior research has identified implicitly require some ideological sympathy between movements. For example, spillover can happen through the exchange of personnel or the sharing of resources like office space (Cress \& Snow 2000). A person is unlikely to work with multiple organizations that have competing goals; such organizations are also less likely to cooperate on day-to-day tasks. Nor are movements likely to form alliances (Van Dyke \& McCammon 2010) or target common firms (Evans \& Kay 2008, Jung, King \& Soule 2014) unless they agree on some dimensions. Other, less relational channels of spillover, such as demonstration effects (van Zomeren, Spears, Fischer \& Leach 2004), require less agreement between two groups. ${ }^{2}$ On balance, though, the prerequisite of contact and association for most channels of spillover should mean that inspiration from social mobilizations should flow to new mobilizations along roughly similar ideological contours. Osmotic mobilization will be greater between groups with ideological affinity; that is, mobilization with firms will likely draw inspiration from mobilization outside of the firm with which there is a shared ideology.

We should also consider how the opportunity structure encourages or constrains osmotic mobilization. This point comes directly from theories of mobilization around and within organizations, which presume that social movements alter the acceptable limits on group formation (Zald \& Berger 1978). Thus for example the spread of legal protection against ascriptive discrimination in the workplace increased the opportunities for organizing around affinity groups (Lichtenstein 2002, Piore \& Safford 2006). It follows that the likelihood of groups' emerging in the wake of social mobilization should be greater in environments where the new groups face less potential opposition. The relative strength of opposition is typically formulated as the political opportunity structure, though we omit "political" when discussing movements that target private organizations. The idea that "exogenous factors enhance or inhibit prospects for mobilization" (Meyer \& Minkoff 2004, p. 1457) has been demonstrated repeatedly (Cooper 1996, Rucht 1996, Clemens 1997), but such demonstrations

\footnotetext{
${ }^{2}$ Indeed, non-relational channels of spillover probably dominate in the formation of counter-movements. At the time of writing, left-wing social movements are explicitly trying to copy the techniques pioneered by the Tea Party in American elections (Indivisble 2017). Such movements rarely share personnel and actively compete for resources.
} 
have involved temporal variations in political opportunities over the history of single movements. Osmotic mobilization should similarly be constrained by such changes in the opportunity structure.

Exploring these theoretical propositions presumes observable variation on all of these constituent dimensions: the level of extra-organizational social mobilization, the ability of successor groups within a firm to advance claims, the ideological overlap between early and later social mobilizations, and the opportunity structure faced in organizations. The empirical challenge here is known. As Zald \& Berger (1978) discussed with regard to their own theorizing:

[T] he propositions imply a sample of organizations to evaluate the structural and dimensional determinants of the occurrence and form of a movement. Often, however, published accounts of occurrence and form are sketchy or nonexistent. Further, it is very difficult to learn about movements which were aborted or suppressed.... Who will describe them for organizations (p. 857)?

Briscoe \& Gupta (2016) make a similar point about extant research on social movements that cross the organizational boundary:

$[\mathrm{M}]$ ore of this research has been conducted through in-depth qualitative studies, rather than through quantitative research. As a result, it has a different feel in terms of forming a base of evidence, generally richer in processual detail but less readily generalizable, relative to work on outsider activism involving social movement organizations (p. 691).

Labor organizing is a setting where we can clear many of these empirical hurdles while making progress on generalizability. The long protest wave itself, with its multiple social movements, gives us variation in claims. Unions as an organizational form vary in their ability to advance such claims; among themselves, they vary on ideological overlap with many social movements' claims. Unions have seen shifts in the opportunity structure for organizing. Finally, as we discuss below, union organizing leaves records of the failed attempts, so we actually can learn about "movements which were aborted or suppressed." There are limits to how much we can generalize from labor unions to other social movements which target firms, limits we discuss below, but we think that these unique empirical features more than justify the effort. We next discuss the context in greater detail.

\section{Labor unions and social movements}

The labor movement historically involved waves of mobilization around economic or class-based claims. Labor unions are also among the earliest examples of social movements that target private 
firms. Organized labor has long posed an ontological problem for social movement and organizational research. To wit: is it a social movement, a collection of formal organizations, both, or neither? For our purposes, a useful way to compare labor unions to other social movements is with Briscoe \& Gupta's (2016) typology of outsider and insider activists, which considers activists' knowledge of and dependence on the targeted organization. The archetypical outsider activist has little detailed knowledge of a targeted organization, but also little dependence on it. Such activists have greater tactical freedom of action, though limited ability to tailor such actions for maximum influence or impact. By contrast, the archetypical insider activist has detailed knowledge but considerable constraint, due to dependence on the targeted organization. Unions are off the diagonal in this typology, since they combine high knowledge with low dependence. We concur with the authors that this type "appears interesting to study, because - from the vantage of the activists - it combines insight into the target organization with freedom from the influence of that target organization" (p. 702). Social movements that want to affect firms should be particularly interested in the potential for such organizations' emergence.

It is important to distinguish between established labor unions and labor organizing. In the United States, "automatic" recognition of a labor union (as happens in countries where collective bargaining happens at the industry level) is virtually non-existent. Thus whenever a union tries to enroll members at new workplaces, mobilization is required. The distinction is important because, as a population of established organizations, most American labor unions predate the long protest wave. The turnover of establishments though requires unions continually to organize new workers if they are to retain their strength; and organizing the unorganized has bedeviled American unions for decades (Goldfield 1987). During and after the long protest wave, the American labor movement suffered steady, grinding losses of power in the private sector. One in three workers were in a union in 1953; one in four were in 1979; fewer than one in ten are today. Spillover from social mobilization that encouraged the emergence of more union locals would be as potentially useful for the labor movement as it would be for broader social movements that want to influence workplaces.

The unions' loss of power raises a potential problem for this study: if labor's strength was steadily declining, why test for spillover here? Research on spillover from broader social movements to organized labor has indeed been slow to develop, and social- and labor-movement research long 
developed in separation. ${ }^{3}$ Scholars in both fields implicitly assumed minimal spillover between the "New Left" movements and labor because of the widely held view that the relationship between the two "was one of consistent separation or hostility" (Isaac, McDonald \& Lukasik 2006, p. 147). That view came from critiques leveled by some activists against "Big Labor" in the 1960s and 1970s for becoming too bureaucratic and professionalized, if not captured by the same firms they were meant to target (Galbraith 1968, Taylor 2007). It also arose because some southern trade unionists took a jaundiced view of the Civil Rights movement, and northern unions had their own practices that had historically limited opportunities for non-white workers (Botsch 1980, Griffith 1988, Nelson 2001).

Even as the "fact" of separation and hostility settled into conventional wisdom and scholarly assumption, though, newer historical work began to undermine it (Jezer 1982, Miller 1987, Levy 1994, Boyle 1995, Cohen 1997, Ganz 2000). More recent quantitative studies show that the long protest wave led to greater rates of union density ${ }^{4}$ in the public sector, though again concluded that spillover in the private sector was negligible (Isaac \& Christiansen 2002, Isaac, McDonald \& Lukasik 2006). We stress that such research has correlated aggregate protest activity and union density. Union density is a very noisy measure of spillover. It is a demographic variable, driven as much by the loss of unionized jobs and workplaces (which social mobilization is not theorized to affect) as by the birth of new ones. For example, job losses in heavily unionized industries and job growth in non-union industries will lower union density, even if worker attitudes or public policy toward unions does not change. If unionized establishments close at higher rates than non-union ones, density will fall (Farber \& Western 2001). Increased political or managerial opposition to labor unions can stymie workers' chances to express their preferences, even if worker preferences change (Ferguson 2008). It is thus possible to see flat or declining private-sector union density even if a protest cycle were to produce osmotic mobilization among labor unions. ${ }^{5}$ We think we can better measure osmotic mobilization here by looking at a more theoretically proximate measure like workers' expressions of support for unions. We focus on union-representation elections because

\footnotetext{
${ }^{3}$ See Conell \& Voss (1990) and Kimeldorf \& Stepan-Norris (1992) for a similar point, and for calls to more closely integrate the two bodies of research.

${ }^{4}$ Union density is defined either as the share of all employees who belong to a labor union or as the share who are covered by a collective-bargaining agreement that a union has negotiated. The two track one another very closely.

${ }^{5}$ Strikingly, these "macro-level" changes moved in opposite directions in the public and private sectors for several decades. Public-sector employment grew while jobs in heavily unionized industries disappeared; people moved in large numbers from the union-friendly Snowbelt to the union-hostile Sunbelt; collective-bargaining rights were expanded for public employees while court decisions and executive actions pared down labor's room for maneuver against private employers (Farber \& Western 2002, Lichtenstein 2002, Tope \& Jacobs 2009).
} 
those elections are the culmination of unions' mobilization efforts at a particular workplace, and the election results directly record workers' support for or opposition to being represented by a union.

Comparing aggregates has another problem: they collapse the variance that we need to test our propositions. Our strategy is instead to exploit variation in levels of protest activity across time and space, and correlate that with variation in union support in these representation elections. Disaggregating the data like this lets us look for influence from the long protest wave on union organizing, even in the context of declining union density.

\section{Hypotheses}

Votes for or against unions in workplace representation elections are a way to test our arguments about osmotic mobilization. Workers who have participated in or observed previous instances of collective action, such as marches, demonstrations, and occupations, are likely more sympathetic to collective action in the workplace, more optimistic that it can produce change, and more knowledgeable about how to do it. Union personnel who cut their teeth in mass protest movements may have a better sense of which workplaces to target for organizing drives, and workers may find such personnel more sympathetic. Organizers and workers with experience in other social movements can bring new tactics into organizing campaigns, and can suggest collective bargaining as a means to press different claims (such as protection from discrimination) against employers. This thinking leads to our first hypothesis:

Hypothesis 1 Higher levels of lagged protest activity will be correlated with higher vote shares for unions in private-sector representation elections.

We have theorized about osmosis because that type of diffusion across a boundary varies by the characteristics of the solutions on each side. That is, we theorize that different characteristics inside and outside organizations should be associated with different levels of osmotic pressure, and greater or lesser mobilization should result. For example, the presence of different types of protest activities outside firms should affect the rate of mobilization within firms. Our data allow us to exploit the heterogeneity in the claims made by protest organizations and the stances taken by unions to see when and where osmotic mobilization was greatest. The bulk of protest activity since the 
early 1960s has been around progressive political causes. If support for unions increases because potential union voters have either observed or been involved in mobilization around progressive political causes, then it is reasonable to predict that osmosis will have a political dimension. We expect that progressive protest activity (in support of Civil Rights, or against the Vietnam War) will have a larger effect on union support within firms than will conservative protest activity (such as pro-War demonstrations, pro-Life protests, and the like).

Hypothesis 2 The positive correlation between protest activity and union vote share will be larger for protests with more progressive claims.

We also theorize that mobilization around issues with more implications for the workplace should exert greater osmotic pressure than more distant issues would. Obvious candidates in this regard are the Civil Rights movement and the women's movement, both of which pressed for the elimination of employment discrimination. This overlap in interests should make osmotic mobilization from Civil Rights and women's mobilization to union organizing more likely (contingent on the specific union involved, which we will explore below).

Hypothesis 3 The positive correlation between protest activity and union vote share will be larger for Civil Rights protest actions.

Hypothesis 4 The positive correlation between protest activity and union vote share will be larger for women's employment-related protest actions.

Hypotheses 2 through 4 focus on the claims made by different extra-organizational social movements, per the argument that similar interests or ideological overlap should imply a more robust channel through which osmosis can occur. In discussing such affinities, it is important to consider the potential new organizations themselves. Unions vary in how progressive their track records have been, historically. Some were early and vocal supporters of black civil rights, others were racially exclusionary; some opposed the Vietnam War, others rallied behind the White House; some welcomed female members, others tried to exclude them (Milkman 1987). We predict that osmotic mobilization should be most likely for unions that took credible, substantive actions in support of issues like black civil rights or opposition to the Vietnam War. More conservative unions would see few benefits, if not actual penalties. 
Hypothesis 5 The positive correlation between protest activity and union vote share will be larger for more historically progressive unions.

Finally, we explore our claim that osmotic mobilization should vary with the opportunity structure that movement activists face in organizations. For the labor movement, the shift from the 1970s to the 1980s marked a major constriction of opportunity, as the failure of labor-law reform and the election of the conservative Reagan Administration signaled to firms that the traditional norms of industrial relations no longer applied (Farber \& Western 2002, Tope \& Jacobs 2009, Western \& Rosenfeld 2011). The late 1970s and early 1980s marked a low point in the effectiveness of union organizing, one that corresponded with changes in the Civil Rights movement. In the 1960s and 1970s, many campaigns to integrate the workplace involved integrating labor unions themselves, and modifying the elements of collective-bargaining agreements, like seniority protections, that disproportionately benefited white workers (Nelson 2001, Lichtenstein 2002). As the 1970s yielded to the 1980s, the elaboration of equal-opportunity legislation and diversity policies within workplaces meant that Civil Rights-related claims could be more effectively pursued through the courts than through collective action (Edelman 1990, Piore \& Safford 2006). We therefore hypothesize that Civil Rights activism would have more influence on union success earlier in the time period under consideration. We treat the years before 1982 as "earlier" in these data, for historical reasons we mention below.

Hypothesis 6 The positive correlation between Civil Rights protest activity and union vote share will be larger earlier in the period than later.

While the 1980s were a period of union retrenchment in many of the industries where black workers had made employment gains (Rosenfeld \& Kleykamp 2012), the opportunity structure was rather different for women. As the women's movement emerged as an autonomous force from activism earlier in the 1960s, many activist organizations also targeted discriminatory employment practices. Protests for equal pay and the removal of "protective" legislation began in the mid-1960s (Davis 1991), but as the 1970s wore on, contentious politics around women's workplace treatment were increasingly focused around attempts to pass the Equal Rights Amendment (Mansbridge 1986, Soule \& Olzak 2004). In addition to being the period of greatest gains in promotion and pay equity for women (Cohen, Huffman \& Knauer 2009), the 1980s and early 1990s were also a period when the labor movement became increasingly feminized, in both the public and the private sector 
(Lichtenstein 2002, Milkman 2006). In particular, women formed a disproportionate share of the occupations, including nursing, clerical, and service work, where private-sector unions made some gains in the 1980s even as union density collapsed in traditional manufacturing. This suggests a telling contrast with our hypotheses about Civil Rights-related osmosis. While we do think that osmosis around women's employment issues will be larger than for outsider activism generally, we also think that such osmotic mobilization will be largest later in the period, rather than earlier.

Hypothesis 7 The positive correlation between women's employment-related protest activity and union vote share will be larger later in the period than earlier.

Hypotheses 2 through 7, which all theorize heterogeneity in the relation of protest activity to union support, also give us an additional way to verify that support for hypothesis 1 is not spurious. Variation in our main effect along a dimension like the protesters' claims or the unions' political orientation implies that unobserved sources of spurious variation must themselves vary along that dimension.

\section{Method}

To test our hypotheses about osmotic mobilization, we examine the relationship between the lagged level of protest in various cities and the vote share that unions receive in representation elections in those cities. Below we describe the data used for the study and the models we estimate, before turning to the results.

\section{Data sources}

Our primary data come from two sources. For information on protest activity, we draw on the Dynamics of Collective Action project led by McAdam, McCarthy, Olzak, and Soule. ${ }^{6}$ To construct a data series on social movement protest, project personnel read every page of each daily issue of the New York Times printed between 1960 and 1995, searching for any mention of protest events. A "protest event" is defined as "any type of activity that involves more than one person and is carried out with the explicit purpose of articulating a claim against (or expressing support for) a target" (Wang \& Soule 2012, p. 1682). Project personnel coded the content of each event, listing

\footnotetext{
${ }^{6}$ For detailed documentation of this dataset, see http://www. dynamicsofcollectiveaction.com.
} 
the claims made, the event's size and location, the targets of the protest, any organizations that were present, the tactics deployed, and any police response. The project yielded descriptions of 23,624 protest events, of all stripes, that occurred in the United States between 1960 and 1995. Strikes and other protests specific to labor unions were not recorded in the DoCA data series. Thus we can assume that any spillover between these protests and union support does not simply reflect campaigning by the unions in question. (We separately control for strike activity.)

Relying on newspaper reporting for information on protests is subject to selection bias and description bias, due to the newspaper's decision to report on an event and to accurately describe what transpired. For the era in question, it is important that the New York Times strove to be the paper of record, covering as wide a range of events and locales as possible. Prior studies have found the Times' coverage of social movement organizations to be considerably more extensive than relying on secondary sources like the Encyclopedia of Organizations Larson \& Soule (2009). Furthermore, the DoCA series' focus on protest events rather than counts of protest organizations allows us to measure variability in the level of protest across time and space. While recognizing its potential limitations, we believe that several of the project's protocols, such as relying on daily reporting rather than weekly summaries or indexes, so as to reduce bias in what news was archived, make this the most comprehensive archive of protest activity currently available. ${ }^{7}$

For union representation elections, we use records maintained in the FAST Database by the AFL-CIO. In the early 1960s, the NLRB negotiated an agreement with the AFL-CIO wherein every month the NLRB would transfer to the AFL-CIO copies of every representation case that had been closed during the month. In return, the AFL-CIO would answer any requests for information about representation elections that third parties made to the NLRB. The records were stored on one of the first mainframe computers installed by a labor union, in this case the federation's Food \& Allied Service Trades division (hence "FAST"). While the AFL-CIO still maintains this archive, the NLRB substantially revised its internal data-management system in 1999; thus both for comparability and because the DoCA series ends in 1995, we use election records running through 1999 in our analyses. A crucial feature for our study is that the FAST data contain records of failed representation elections as well as successful ones. This is what allows us to study changes

\footnotetext{
${ }^{7}$ Several of our robustness checks are additionally aimed at assessing potential bias introduced by relying on the Dynamics of Collective Action series.
} 
in expressed support for unions, separately from density. The NLRB has jurisdiction over privatesector workplaces, hence our concentrating on union organizing in the private sector.

While our union election data include information on union wins and losses, they are subject to a different form of sample selection, namely, which establishments unions chose to target for unionization. This is important because it suggests a different channel through which protest by outsiders could become positively correlated with mobilization by insiders. If protest activity caused unions to change the types of establishments that they target for unionization (through encouraging new groups of people to become union organizers, for example, or by altering the composition of workplaces in ways that make them more attractive to unions), then we could see a positive correlation between protest activity and union vote shares even if outsider activism had no direct effect on insiders' willingness to take collective action.

Data on whether unions go through with elections (rather than withdraw) are not currently available before 1999 (Ferguson 2008), and even the most ambitious attempts to model the risk set of establishments that unions could target face similar data limitations (Dinlersoz, Greenwood \& Hyatt 2014). Thus directly testing whether and how outsider activism altered unions' targeting behaviors is beyond the scope of our data. However, two points should reassure us that this is not a critical problem. First, there is almost no indication that unions drastically changed their organizing strategies before the late 1980s at the earliest. Quite the opposite - during the years of union decline, the common lament was that unions were not responding to changes in workplaces and workers (Craft 1991, Delaney, Jarley \& Fiorito 1996). To the extent that some unions did begin to reform their targeting and organizing practices in recent decades, this would be ground for skepticism about evidence supporting hypotheses 6 and 7, but not the others. (In robustness checks, we also test our results excluding all activity after 1981.) Second, changes in the composition of workplaces that might make them more attractive to unions would include increased minority employment. Data on workforce composition for this period that can be matched to union-election data are not available, but research on this question for more recent years has found that increased workforce diversity increases the difficulty of union organizing (Ferguson 2016). To the extent that we find a positive relationship between outsider protests and insider votes in the establishments where elections were held, such selection would imply that our results are a conservative test.

Data for our control variables come from several sources. The size of the proposed bargaining 
unit and information about whether an incumbent union was on the ballot come from the FAST database. Other data sources we describe as we introduce the relevant control variables.

\section{Dependent variable: Union vote share}

To operationalize workers' support for unions, which protest is theorized to increase, we use the votes that unions receive in representation elections. The National Labor Relations Act governs trade-union formation in the private sector. Its primary mechanism is the secret-ballot election regime overseen by the National Labor Relations Board. Any union, individual, or employer can petition the NLRB to hold an election at an establishment, in which the employees can vote whether

they want a given union to be their representative for purposes of collective bargaining with the employer. Along with the petition itself, the petitioner must submit cards, signed by at least 30 percent of the members of the proposed unit, saying they wish such an election to be held. In these elections, a simple majority of the votes cast determines the outcome. The NLRB records the number of eligible voters, the number of votes cast and the number of votes in favor of unionizing. We calculate the vote share as the votes for the union over the votes cast.

Figure 1 shows the distribution of vote share across the establishments in our data. A striking feature of union-election data is the large number of elections where the vote share can be zero or one. This is driven by the many small bargaining units (ten or fewer employees) in the election data. There are also more "ones" than "zeroes" in the data. This reflects how unions can withdraw petitions and cancel elections in units where they think they are likely to lose. These clusters of complete support for or opposition to the union do not complicate model estimation, but they do complicate interpreting the results. If there is any correlation between outside activism and the probability of a zero or one vote share, then the preponderance of ones over zeroes can bias upward the estimated effects of the independent variable. As it happens, union campaigns targeting small workplaces are more common in larger cities, which have more protest activity and are more prounion on average. This correlation could bias upward the estimated effect of protest on union vote shares, for reasons that have nothing to do with the process theorized here. We therefore exclude those elections where the union received none or all of the votes. Figure 1 shows the distribution of this trimmed variable. We conduct robustness checks to show that our results are not substantively altered if we include the extreme vote shares. 
[Figure 1 about here.]

It should be emphasized that the average union vote share was not increasing during the long protest wave. Rather, as figure 2 shows, average vote share declined steadily until 1982, after which it rebounded somewhat. Because the choice by unions to hold elections rather than withdraw their petitions is a choice variable (Ferguson 2008), it is unclear how much of this decline represents falling support for unions among work groups that traditionally supported them and how much represents a failure of unions to adapt their targeting of establishments to changing attitudes or conditions. Yet in either case the secular trends in vote share are useful for us, because we know that any positive correlation between protest activity and vote share does not just reflect common increases in the two variables.

[Figure 2 about here.]

\section{Independent variables: Protest activity}

Our main independent variable is the level of protest activity in a metropolitan area in the period before a union election. We generate a count of protest events in the relevant area in the five years preceding the year of the union election. We think that the effect of the level of protest activity is probably multiplicative - that for example increasing the number of protests from one to twenty is more important than increasing from 101 to 120. Thus we take the natural log of the count. Doing so also helps resolve the skewness of the count variable. When we build similar variables to track progressive, Civil Rights, and women's-movement protest activity, we rely on the claims made by each protest, as recorded in the $D o C A$ dataset. Detail on which claims we used is in appendix A.

Calculating these variables involves making choices about how to define a metropolitan area and which period to choose. Both the DoCA and the FAST data record the city where their respective events take place. Yet this seems too restrictive a unit of analysis. To take the city as our focus, we would have to presume that protests in Evanston have no effect on union activity in Chicago; that Newark is equally isolated from Jersey City; Arlington from Washington, DC; Oakland from San Francisco; and so on. At a minimum, we would like a spatial unit broad enough to encompass both where people live and where they work. This matters because much protest activity, particularly that related to the civil rights movement, often takes place in the protesters' own communities, 
while union elections happen at their workplaces. For our analyses, we map cities to the core-based statistical areas, or CBSAs, defined by the Office of Management and Budget. CBSAs are based around an urban center of at least 10,000 people and adjacent areas that are tied to it through commuting. The CBSA definitions that were promulgated by the OMB in 2000 comprise both Metropolitan and Micropolitan Statistical Areas, as well as the New England County Metropolitan Areas. The OMB defines 929 CBSAs in the United States. ${ }^{8}$

For time period, we use the previous five years. Our choice is partly driven by practical concerns: we do not want to throw away too many early-period elections by requiring too long a lag on protest activity. But our choice is also driven by theory: if one of the channels of social movement spillover is the migration into the workforce of young people (in particular) who participated in protest, then it is appropriate to factor in the effects of more temporally distant as well as recent protest activity. We have tried replicating our results with lags varying between three and eight years, and find substantively similar results.

In addition to the level, we also calculate the median size of protest activity in the CBSA over the five-year period. For this we draw on records of the number of protest participants in the $D o C A$ data. We use the median rather than the mean because the latter is severely affected by a handful of very large protest events, such as the March on Washington in 1963 or the MayDay activities against the Vietnam War in 1971 (DeBenedetti 1990).

Figure 3 shows the count of both protest events and union-representation elections by year. There is no strong year-to-year correlation between the frequency of the two types of events. However, both protest and union-organizing activity decline precipitously after 1980 (Tope \& Jacobs 2009). The correlation in the levels of the two activities across decades raises the concern that both may be driven by a common, unobserved trend that varies by time. This motivates our controlling for year fixed effects in our analyses. The break in the protest and union-organizing time series, as well as the change in the union vote-share series shown in figure 2 , together motivate our decision to break the data at 1981 when testing hypotheses 6 and $7 .^{9}$

[Figure 3 about here.]

\footnotetext{
${ }^{8}$ Maps of the CBSA boundaries can be found at http://www2 . census.gov/geo/maps/metroarea/us_wall/Dec_2009.

${ }^{9}$ A break-point around 1981 also corresponds with similar analyses by Tope \& Jacobs (2009) and Farber \& Western (2002).
} 
In addition to varying over time, both protest and union activity vary across space. Both types of events are clustered in metropolitan areas, though not necessarily the same areas. Tables 1 and 2 show the top 25 CBSAs ranked by their levels of protest activity and organizing activity, respectively. Thirteen city areas appear on both lists. The clustering of both activities in a comparative handful of cities might indicate that, as with the variation over time, the levels of both protest activity and union support might be driven by unobserved differences in the environment of different city areas. This motivates our controlling for CBSA-level fixed effects in our analyses.

[Table 1 about here.]

[Table 2 about here.]

Finally, "organized labor" is by no means a homogeneous actor. The various labor unions have their own histories and track records with regard to issues like race relations, support or criticism of American foreign policy, and openness to female members. We have hypothesized that protest around progressive causes would spill over into support for unions with more progressive track records. As table 3 shows, the organizing drives in our data are clustered, such that the 25 mostactive unions account for more than four fifths of all activity. Thus, as with years and city areas, it makes sense to control for union-level fixed effects in the following analyses.

[Table 3 about here.]

\section{Control variables}

We include controls at the level of the establishment and at the level of the CBSA. In each case we focus on factors that vary across cities and over time, that is, on factors that would not be absorbed by fixed effects for CBSA, year, or union. Even though our units of observations are specific union representation elections, many of these variables are measured annually for each CBSA; thus all of our models cluster their standard errors by CBSA and year.

At the establishment level, unit size has a well-documented negative relationship with election success (Farber 2001), and including it allows us to control for any heterogeneity in the size of establishments targeted by union organizers in different times and places. We therefore control for the logged number of eligible voters included in the FAST election record. We also control for 
whether there is an incumbent union on the ballot. The vast majority of union elections are held as attempts to establish a union where there was not one before, but some are focused on decertifying one union in favor of another. If there are differences in the frequency of such attempts, controlling for incumbency will partial that effect out. The presence of an incumbent on the ballot is also indicated in FAST records.

The $D o C A$ data do not include strikes by labor unions, but it is obviously important to control for such labor-related protest events. We include strike data for the years before 1978 using the Work Stoppages Historical File compiled by the Department of Labor. After 1981 the Labor Department stopped compiling regular data on strikes that idled fewer than 1,000 workers. For years after 1982 we rely on the archive of work stoppages compiled by the Federal Mediation and Conciliation Service. Detailed data on strikes in the private sector are unavailable between 1978 and 1982. We interpolate strike levels for CBSAs between 1978 and $1982 .{ }^{10}$ The historical strike data only record the state where the strike happened. Thus we aggregate our annual counts of strikes at the state level. ${ }^{11}$ We use the same five-year temporal structure as we do with other protests.

Differences in the political orientation and control of government can affect both the toleration and perceived efficacy of protest and the success of union activity. We control for the conservative politics of the CBSA in which the representation election takes place. We draw on the county-level votes from each presidential election between 1960 and 2000. In each county, we take the vote share received by the more conservative candidate (or candidates, as when Richard Nixon and George Wallace both contested the 1968 election). For each CBSA we generate a conservative vote share as the weighted sum of each county in the CBSA's conservative vote, where the weights are each county's votes cast. We linearly interpolate between election years to compute a conservativepolitics score for each CBSA in each year.

Because union elections are more likely to succeed where unions have historically been strong, and because places with strong histories of collective action may be more likely to sponsor new types of collective action (Greve \& Rao 2012), we control for the state union density in a given year, using the data that Hirsch \& Macpherson (2004) compiled from the Current Population Survey.

\footnotetext{
${ }^{10}$ We tried excluding observations that rely on these years' strike levels, and get similar results.

${ }^{11}$ The post-1982 records include the strike city. We replicated models on the post-1982 data using lagged strikes aggregated by city and by state, and get similar results.
} 
Unemployment both weakens the strength of unions and can increase the incidence of protest, so we control for the unemployment rate in each state-year, using either the Bureau of Labor Statistics' Local Area Unemployment Statistics series or (before 1976) figures calculated from the CPS.

Unions have been more successful organizing in larger cities, and larger CBSAs have more protest activity. We use data taken from the decennial census, supplemented by the annual CPS, to control for CBSA population size. Since at least the late 1960s, black workers have been more inclined to vote for unions than those of other races (Rosenfeld \& Kleykamp 2012). Our data include many protests, particularly around civil rights, that disproportionately involved black citizens. Thus we control for the annual black share of each CBSA's population, using the same sources. Finally, we control for the annual CBSA employment share in manufacturing, since employment shifts associated with growth or decline in this traditional union stronghold could both affect labor support and trigger public unrest (Sugrue 1996). Before 1968, manufacturing share can only be calculated at the state level; afterward, we use the share at the CBSA level.

Tables 4 and 5 present summary statistics and bivariate correlations of the variables used in the analyses.

[Table 4 about here.]

[Table 5 about here.]

\section{Models to be estimated}

Our empirical strategy is to estimate the correlation between lagged protest activity and votes for unions in representation elections. Our unit of observation is the representation election. Our analysis has two main parts. First, we build out a series of fixed-effect models to explore whether any association we find between the two variables persists when we control for various sources of unobserved heterogeneity between the cases. These models allow us to test hypothesis 1 . Second, we reproduce those models using more restrictive versions of the independent variable, focusing on progressive, Civil Rights, and women's-movement protests, to test hypotheses 2 through 7. Third, we subset these linear models by union and year to explore whether the strength of osmotic mobilization varies by union. Exploring effect heterogeneity for unions is necessary to test hypothesis 5. In robustness checks, we also estimate the parameters of a two-level hierarchical model in which 
we allow the effects of protest to vary randomly by city, year, and union.

Our dependent variable, union vote share, is a proportion bounded between zero and one. We prefer to estimate vote share and then calculate union wins and losses, rather than estimate victory directly, because the former approach is more statistically efficient, uses all available information, and is more useful for computing counterfactual predictions (Gelman \& Hill 2007). That said, in robustness checks we replicate our analyses using a binary win/loss variable, and find no substantive difference in the size or significance of our estimated coefficients.

We estimate the proportion of votes for the union using a general linear model. Elections are observed at the level of specific establishments. Let $v_{i k t u}$ be the vote share received by union $u$ in establishment $i$ in city $k$ in year $t$. In its simplest form the model can be written as

$$
\ln \left(\frac{v}{1-v}\right)=\mathbf{X} \beta, v \sim \text { Binomial. }
$$

In this case vote share is assumed to follow a binomial distribution (as is typical with an outcome that is the aggregation of i.i.d. Bernoulli random variables), and $\ln \left(\frac{v}{1-v}\right)$ is the logit link function that maps the linear results onto the correct cumulative distribution (i.e., one that maps unbounded linear predictions onto the $[0,1]$ probability interval). In the special case where all vote shares equal zero or one, this specification reproduces the standard logit model.

We theorize that vote share will be driven in part by levels of protest activity. Of course, many other factors can affect the level of support a union receives. In our full model, we specify $\mathbf{X} \beta$ as follows:

$$
\ln \left(\frac{v_{i k t u}}{1-v_{i k t u}}\right)=\theta+\mathbf{p}_{\mathbf{k}(\mathbf{t}-\mathbf{l})}^{\prime} \beta+\mathbf{x}_{\mathbf{i k t u}}{ }^{\prime} \gamma+\mathbf{w}_{\mathbf{k t}}{ }^{\prime} \delta+\left\{\kappa_{k}, \tau_{t}, \psi_{u}\right\}+\epsilon_{i u}^{(k t)}
$$

where:

- $\mathbf{p}_{\mathbf{k}(\mathbf{t}-\mathbf{l})}$ contains city-year variables measuring protest activity over the previous $l$ years

- $\mathbf{x}_{\mathbf{i k t u}}$ contains controls that vary by establishment

- $\mathbf{w}_{\mathbf{k t}}$ contains controls that vary by city-year

- The vectors $\kappa, \tau$, and $\psi$ contain fixed effects for city, year, and union, respectively. 
We cluster $\epsilon$ by city-year to account for the non-independence of the observations of protest activity, which is measured at the city-year level.

Because we measure protest activity at the level of the city-year, we cannot include city-year fixed effects. Nor can we include all three sets of fixed effects in the model, as doing so would swamp any variation in protest activity. Instead we introduce these effects singly and in pairwise combination. While we cannot include city-year fixed effects, we can include city fixed effects and year fixed effects; that is, we can control for unobserved heterogeneity between cities that is constant over time, as well as unobserved heterogeneity over time that is stable across cities. We can also control for persistent unobserved differences among unions. These fixed effects underlie our identification strategy: in addition to our explicit controls, the fixed effects allow us to control for any unobserved differences in both protest levels and union support across cities, across years, and across the unions involved in the elections. This sharply constrains the possibilities for omittedvariable bias. Any such confounding variable would have to be one that covaries with protest activity and union support, across space and time, with the same lag structure.

To explore heterogeneity of osmosis by union, we fit separate sub-models for each union. In order to test hypothesis 5, we classify unions into progressive, neutral, and conservative sub-classes (see appendix B for details on this procedure). We then estimate a weighted average effect of protest for each sub-class. In robustness checks, we also compare these results to those obtained from a hierarchical model that allows for crossed random effects by city, year, and union.

\section{Results}

Table 6 presents our GLM results for union vote share as a partial function of the level of protest activity. Model 1 shows the correlation of lagged protest activity with vote share. The estimated coefficient is positive and significant at the .01 level, which supports hypothesis 1.

Model 2 separately controls for the size of the median protest event, alongside the overall protest level. We include model 2 here to demonstrate that our main effect is robust to measurement of protest size, but we also want to explain why we do not include size in all of the later models. First, including protest size changes the interpretation of the protest-level variable. Because the size variable is not defined in city-years wherein no protest occurred, model 2 estimates the variation 
in vote share by protest activity only among the city-years that had some protest events, hence the drop in observations. Second, separately controlling for level and size means that the size coefficient shows the effect of increasing the median protest-event size while holding the level of protests constant. Our data only have enough repeated measures of protest level to gain statistical power on the variable at a few levels of protest activity, so this coefficient is estimated on a subset of the data. One alternative would be to compute a count of protest events weighted by protest size, essentially trying to count how many people turned out for protests in a CBSA over a given time period-but this has problems of its own, including likely repeat counting due to people attending multiple events. Thus we have chosen to focus on protest level for our subsequent analyses. Model 2 is nonetheless important, as the significance of the protest-level variable shows that the effect in model 1 is not reducible to the difference between having some versus no protest activity.

[Table 6 about here.]

Model 3 introduces our establishment-level controls. Both of these effects move in the directions predicted by prior work. Union elections are less likely to succeed in larger bargaining units, as prior work has found. Unions are more likely to win elections when they are trying to unseat an incumbent union.

Model 4 introduces our city-year-level controls. Unions are less likely to win in more politically conservative places and at times of greater unemployment, and more likely to win in states with greater union density. One surprise in the control variables is that unions are less likely to win elections in cities with larger shares of their workforces employed in manufacturing. We suspect that this reflects that unions had some of their largest and earliest successes in cities heavily dominated by manufacturing. By the era under study here, many such cities were entering periods of sustained economic decline (Cumbler 1989, Sugrue 1996), which has been sectorally associated with lower support for unions (Goldfield 1987).

In table 6 the coefficient on protest level is significant and stable, ranging from .013 to .026. It is important to put this effect size in context. In model 4 for example, it implies that holding all of the other variables at their means and increasing the logged protest level by one standard deviation would increase the expected union vote share by .78 percentage points. ${ }^{12}$ Given that

\footnotetext{
${ }^{12}$ We calculated the marginal effects discussed here with the margins command in Stata 14.
} 
the average margin of victory in representation elections is 2.8 percentage points, this effect size is substantial. We can apply this increase to the elections observed here, and calculate that a .78-percentage-point increase in the union vote would have flipped an additional six percent of the elections to union victories, and would have resulted in an additional 294,833 union members. This of course is just the most direct effect. It is reasonable to assume that increases in union density would also imply increases in union organizing, in which case the total increase in membership resulting from increased protest might be larger.

The models in table 7 expand on model 4 from table 6 by adding vectors of fixed effects. As discussed above, we fit these models to investigate whether the effect on vote share that we attribute to protest might in fact be due to some unobserved differences across years, cities, or the unions involved. Models 5 through 10 show that this is not the case. While some of the effect may be attributable in particular to differences in the unions involved, the main effect of protest level remains positive and significant at the .01 level in all of these models. ${ }^{13}$

[Table 7 about here.]

Taken together, the results in tables 6 and 7 provide strong support for hypothesis 1, that there are positive spillovers between outsider protest activity and insider mobilization through union representation elections. In particular, the models in table 7 rule out the possibility that this relationship merely reflects unobserved differences across time periods, cities, or unions.

We next turn to hypotheses 2 through 4, which test how such spillover varies by the type of claims made by outsider activists. Table 8 replicates model 4 with different types of protest counts. Model 11 shows spillover from lagged protests coded as making politically progressive claims. The estimated coefficient, .015, is larger than the .013 from model 4, and a Wald test indicates that the difference is significant at $p<.02$. This lends support to hypothesis 2 , however, the substantive difference in effect size is not very large. The story is very different when we concentrate on Civil Rights-related protests. As model 12 shows, if we focus on Civil Rights protests during the long protest wave itself-modeling only those elections held through 1981, and thus influenced by protest activities through 1976-the estimated spillover is nearly three times larger than for the

\footnotetext{
${ }^{13}$ Models with industry fixed effects produce similar results and are available on request. We do not present industry results here for reasons of space, and because specific union organizing is correlated with industry, owing to many unions' industrial jurisdictions.
} 
sample as a whole. This supports hypothesis 3. The results for employment-related protests by the women's movement are starker still. The pooled coefficient for such protests yields a coefficient of .048 $(p<.01)$. Models 14 and 15 show estimates by time period. Even before 1981, women's employment-related protests are associated with nearly twice as large a spillover effect on insider mobilization than for the sample as a whole. This supports hypothesis 4 .

[Table 8 about here.]

Hypothesis 5 is that there will be more osmotic mobilization to unions with more progressive reputations. Subsetting the data by union produces nearly 100 separate coefficients. We therefore also consider the weighted average effect on progressive, neutral, and conservative unions. Figure 4 summarizes these results. For the majority of unions, protest activity has no significant spillover, as indicated by the faint lines in the figure. For many unions, this owes as much to sample size as to effect size. Despite progressive records on racial integration and/or early opposition to the Vietnam War, for example, unions like the $\mathrm{UE}^{14}$ or the NUHHCE simply had too few organizing drives to estimate statistically significant effects. Nonetheless, the bulk of unions that did experience positive spillovers from protest were progressive ones - unions such as the SEIU, the HERE, the UAW, the RWDSU, and others that prior studies have either singled out for their liberalism during the period (e.g., Boyle (1995)) or discussed as promising candidates for revitalization later on (e.g., Voss \& Sherman (2000)). By contrast, it would seem that, in the wake of external protest activity, the presence of conservative unions make the organizational boundary even less permeable.

\section{[Figure 4 about here.]}

Figure 4 also summarizes the weighted average spillover for each of these three sub-classes. It is clear that osmotic mobilization was essentially experienced by progressive unions, and progressive unions alone. Their average effect, .014, is almost exactly opposed to the negative spillovers, -.013, experienced by more conservative unions. Because campaigns by more progressive unions comprise the majority of all organizing attempts in the data, the main effect of protest-union spillover is positive. Nonetheless, these differences by political orientation lend strong support to hypothesis 5.

\footnotetext{
${ }^{14}$ Union names are expanded in appendix B.
} 
Finally, models 13 and 15 in table 8 test hypotheses 6 and 7, by examining whether the effects of protest vary with changes in the opportunity structure faced by the social movements and organized labor. Model 13 shows that Civil Rights-related protests after 1981 are not associated with particularly large levels of osmotic mobilization, even though the coefficient remains positive and significant (a Wald test of the protest coefficients in models 12 and 13 suggests differences significant at $p<.01)$. Meanwhile, in the period after 1981, which includes the lagged effect of mobilization around the Equal Rights Amendment, the estimated effect for women's-movement protests is more than 2.5 times as large as before 1981 (the difference between these coefficients is significant at $p<.01)$. We want to take care not to generalize from this coefficient to the whole

sample. There were fewer organizing events after 1981, and unions had clearly started to alter their targeting and organizing activities, as the change in the vote-share trend in figure 2 indicates. Nonetheless, this pattern of results is completely in line with the mobilization of collective action among women and the feminization of union organizing in the private sector, parallel with what Isaac, McDonald \& Lukasik (2006), Rosenfeld (2014), and others have found in the public sector. Together, these two models constitute support for both hypotheses.

\section{Robustness checks}

We had two primary concerns related to the choice of our models. The first concern was whether our pattern of results was being generated by particular clusters of observations. The second was how sensitive our results were to our choice of the general linear model with a logit link to model vote shares. Accordingly, we present two sets of robustness checks.

Table 9 reproduces model 4 while excluding specific groups of observations. Model 16 excludes all observations from the CBSA centered on New York City. Our data on protest activity come from the New York Times, and New York is quite a labor-friendly city compared to the country as a whole; thus it is reasonable to worry that our effect might be driven by any disproportionate coverage of protest activity in the greater New York area. Yet as model 16 shows, excluding New York has little impact on the estimated size of spillover. Model 17 reproduces the procedure while excluding all organizing drives launched by the International Brotherhood of Teamsters. The Teamsters have been by far the most active organizers over the last half century - by itself the IBT accounts for more than 30 percent of all organizing activity. Particularly because we have coded the 
Teamsters as a progressive union, ${ }^{15}$ there is a risk that anything idiosyncratic to the Teamsters could drive our results. Yet, again, setting their observations aside does not significantly alter our results. Finally, we have built most of our theory around the impact of the long protest wave that scholars typically date as running from about 1960 to about 1980 (Isaac \& Christiansen 2002). Neither protests nor union organizing stopped after 1980, so we have included subsequent observations in our data, as well as hypothesized differences in effect size between the periods, but it would vitiate our argument if the bulk of any observed effect was due to later protest activity. Thus model 18 excludes observations after 1981, when Isaac, McDonald \& Lukasik (2006) for example stop their data series. We find that, when focusing on elections between 1965 and 1981, our observed effects are even stronger. We thus feel confident that our main results are not driven by particular clusters of unusual observations.

[Table 9 about here.]

We next focused on our choice of the GLM model specification and our specific measure of vote share. Table 10 reproduces model 4, using different outcome measures or model specifications. As we discussed above, we chose to look at elections where the vote share was between 0 and 100 percent, because we were concerned that the over-representation of 100-percent election returns could bias our findings in favor of our hypotheses. Model 19 in table 10 shows that this is the case. Using a non-trimmed measure of vote share increases the estimated size of protest-union spillover by about 30 percent. Nonetheless, the general pattern remains unchanged. Model 20 replaces the GLM with a simple OLS regression of vote share on protest activity and other controls. The effect of vote share remains significant in this specification. Similarly, model 21 models the outcome of interest as a binary win/loss, rather than focusing on vote share; again, the effect of protest activity is quite stable. It is the stability of the estimated effect of protest activity on union vote shares across tables 9 and 10 in particular that lends credence to our contention that this estimated effect is not particularly sensitive either to our choice of observations nor to our model specification.

\footnotetext{
${ }^{15}$ Our decision to code the Teamsters as progressive might itself seem surprising. Jimmy Hoffa, after all, may be the most famous corrupt union boss in popular memory. The IBT though was and is a strikingly diverse and decentralized union (Lichtenstein 2002, p. 145), one that early on admitted large numbers of black members, that campaigned for pay equality, that partnered with the UAW in forming the breakaway progressive Alliance for Labor Action in the late 1960s, and so on. Furthermore, the IBT has often contained insurgent factions, such as Teamsters for a Democratic Union; and the union has never lacked for militancy, organizing for example a famously successful international strike against UPS in 1997 (Banks \& Russo 1999). That said, removing the Teamsters from our analyses alters none of our substantive results.
} 
[Table 10 about here.]

We tested hypothesis 5 by sub-setting the data by union and estimating an intercept and coefficient for protest for each. For most unions, we do not have enough observations to control for unobserved heterogeneity by city and year within these sub-models. This allows for the possibility that what we label union heterogeneity may be an artifact of the non-random clustering of union activity across years (when controlling for city) or cities (when controlling for years). One way to test the robustness of our result is to fit a hierarchical linear model, one that includes random effects for city and year as well as for union (Raudenbush \& Bryk 2002). The basic logic in such a model is that it allows the intercept and the coefficient for protest to vary by unions, while also allowing the intercept to vary by city and year. In this model, we treat the representation elections as the "level-I" observations. We assume that vote share in an election is a function of the "group memberships" - the city, year, and union associated with each election- denoted $\pi_{0}$, and a union-specific effect of protest activity, denoted $\pi_{1}$ :

$$
v_{i k t u}=\pi_{0}+\pi_{1} P_{k t}+\epsilon_{i k t u}
$$

Level II models the expected vote shares and effects of protests associated with different cities, years, and unions:

$$
\begin{gathered}
\pi_{0}=\gamma_{0 u}+T_{0 t}+K_{0 k}+\omega_{0, \mathbf{k t u}} \\
\pi_{1}=\gamma_{1 u}+\omega_{\mathbf{1}, \mathbf{u}}
\end{gathered}
$$

In the level-II equations, $\omega$ represents the variance components associated with the random effects and their combinations. As with the fixed-effects models, we cluster the standard errors in the level-I model by city-year to account for protest activity's being measured by city-year. Table 11 reports the analysis of variance resulting from models where we constrain the effects of protest to be uniform for all unions, and where we allow the effect to vary. In both cases where we allow for separate union-specific slopes, model fit is significantly improved. The union-specific coefficients produced in these models are also substantively similar to what we report from the sub-set models 
above (full results are available on request). This additional analysis increases our confidence that the variance in protest's effect is indeed due to different union behaviors.

[Table 11 about here.]

\section{Discussion}

We have little research on when extra-organizational social movements encourage the emergence of mobilizations inside organizations that target those organizations. It follows that we do not understand the contingencies that determine when this process, osmotic mobilization, will be stronger or weaker. We have theorized about movement or organizational characteristics that would raise the osmotic pressure in such spillover: resources that can further the external movement's claims, ideological overlap on those claims, and variation in the opportunity structure within organizations. We have explored these ideas using data on the relationship between public protests and union representation elections during the long protest wave, between 1960 and 2000. We found that higher levels of public protests were associated with greater support for labor mobilization within private-sector firms, and that such spillover is heterogeneous. Ideological and interest overlap between outsider and insider activists predicts greater spillover. Osmotic mobilization happened disproportionately to unions with politically progressive track records. This was particularly so when outsiders mobilized around employment-related issues that labor unions are well placed to help advance. What is particularly nice about this pattern of results is that many case studies have characterized some unions as more activist or transformative than others (e.g., Voss \& Sherman (2000), Clawson (2003), Martin (2008a)). Our findings indicate that these unions effectively raise the osmotic pressure for progressive protests in the organizations where they try to represent workers. Thus we see a pattern hypothesized in small- $n$ work supported in more representative data.

For organization theorists, the real payoff from understanding this process lies in specifying the channels through which external pressures ultimately affect firm outcomes. Some channels, like legislative change, are clear (Dobbin \& Sutton 1998, Dobbin, Sutton, Meyer \& Scott 1993). Others, like shareholder activism, can also be effective but will vary more by characteristics of the firm targeted (King \& Pearce 2010). Mobilization of the firm's workers, as opposed to its owners or 
powerful external stakeholders, has received less attention in recent research. Yet organizations like unions are potentially critical candidates for spillover, because they tend to combine high knowledge of and influence on the firm with low dependence on it, and thus comparative freedom of action (Zald \& Berger 1978, Briscoe \& Gupta 2016). Despite their weakness today, for decades the labor movement helped channel extra-organizational demands into formal organizational routines and practices (Slichter, Healy \& Livernash 1960, Kochan, Katz \& McKersie 1986, Edelman 1990). Mobilization of workers and their formal organizations is part of any general understanding of how contentious politics might play out in private organizations (Davis, Morrill, Rao \& Soule 2008). In this discussion, we want to clarify the contributions and limitations of our study, then its broader implications for future work in social movement, labor, and organizational research.

Our research design lets us argue strongly for a causal effect of osmotic mobilization and the determinants of its variation here. The rich set of fixed effects that we include rule out most sources of spurious correlation between protest activity and union support. The pairwise combinations of fixed effects further restrict the possible confounds. This would mean that any confound would have to vary by city and by year, with the same pattern of temporal variation present in our protest measure. We also control for the most likely correlates of union support that vary by city and year, such as the unemployment rate, political control, and demography. Therefore, while it is notoriously hard to make causal statements from observational data, we think that these results clear a very high bar.

Causality and generalizability are separate concerns. As we discussed above, union elections only happen where organizing drives have had some measure of success. If the union thinks its chances are hopeless, it will withdraw and leave no record in these data. The most conservative way to interpret our findings is to say that they apply to organizations where there was already some threshold level of sympathy for organized labor. This does not reduce the generalizability a priori, but if there are theoretical reasons why we would expect different behavior from, say, manufacturing workers rather than professionals, that would apply here. Some portion of the observed effect may also reflect how unions changed their organizing behavior in the wake of protests, rather than how protest changed workers' views of unions. We think that this sample-selection issue would tend to understate the results we find here, ${ }^{16}$ but we do not think it would significantly alter the theoretical

\footnotetext{
${ }^{16}$ Negative osmotic mobilization might exist if protest participants distrusted unions and could make unions alter
} 
propositions we advance.

Yet there are boundary conditions on the theoretical conclusions we draw from these findings. Historically, the labor union is not a rare form for mobilization to take. Half a century ago, nearly one in three private-sector workers in the United States was a union member; the rate was and is higher in many other industrialized nations. Yet it is an atypical form. As we have discussed, most "insider activists" (Briscoe \& Gupta 2016) are more dependent on their host organization and have less freedom of action than the typical union. They may have limited ability to take public positions on issues that matter to outsider activists but that are orthogonal to their organizational purpose. In practice we might observe less variation in the strength of osmotic mobilization among less autonomous insider activists, not because ideological overlap is unimportant but because such activists have less latitude to express their preferences. Similarly, the specific opportunity structure for other types of firm-targeting mobilizations may be harder to define and measure. Here we could exploit changes in political control and enforcement that affected the common legal infrastructure underpinning unionization. Thus we could operationalize broad shifts in the opportunity structure using period effects. Such identification would be harder among more heterogeneous mobilizations.

We should also underline how osmotic mobilization differs from most extant work on the relationship between outsider and insider activists. That research considers activists on both sides of the firm boundary while holding the firm, and usually the activists' claims, constant. Thus studies might look at the relationship between public protest and shareholder resolutions around disinvestment by specific corporations (Soule, Swaminathan \& Tihanyi 2014), or the orientation of firms toward outsider agitation around a single issue like domestic-partner benefits (Briscoe \& Safford 2008). We seek to understand something broader: how social movements, even when they are not targeting specific organizations and policies, can provoke or support the emergence of mobilization that does target organizations. At the level of the specific firm or claim, there may be little scope for ideological variation. Outsider and insider activists may almost by definition face the same opportunity structures. We would expect variance on these dimensions to be smaller and less important for our theories. At a greater remove, though, they matter.

the set of establishments they target. In such a case, our results could overstate effects. But this would require any such negative-spillover effects on unions' targeting behavior to swamp the positive-spillover effects on workers' voting behavior. We have trouble imagining how this could work. In any case, the empirical answer depends on better data about the earlier stages of union organizing drives. 
We have taken no position on the specific mechanism that produces the correlations we find here. This is not because we think it unimportant but because the types of relational, non-relational, and mediated mechanisms that social movement research has identified (Givan, Roberts \& Soule 2010) all yield similar predictions here. Osmotic mobilization can happen for example because one-time Civil Rights marchers later support unions in their workplaces at higher rates, but also because union organizers who once marched go on to target different firms than their peers. Alternatively, workers might observe the efficacy of collective action without participating themselves, and later support such mobilization in their firms. We cannot distinguish such mechanisms here - with these historical data, we are probably at the limits of what detail can be resolved. ${ }^{17}$ But this is precisely where the prospect for future work become exciting. The challenge for untangling the mechanisms of osmotic mobilization lies in knowing which individuals overlap between mobilizations and organizations, and in knowing individuals', groups', and organizations' opinions on the claims made by different social movements. Gathering data on this will never be easy, but today it is at least feasible. Social media offers more detail on protest events and individual attendance than ever before; press releases and other statements by organized actors are archived better than in the past. One could imagine tracing a person's (public!) Instagram photos from Zucotti Park during Occupy Wall Street, their employment via a résumé on LinkedIn, and their membership in an anti-sexual-harassment group on Facebook. Could we predict where the next wave of employmentrelated activism will appear or spread, based on such data? These links are more distant than what most outsider/insider research has explored to date, but they relate to the process of osmotic mobilization theorized here.

This study also has implications for the indirect effects of osmotic mobilization. For example, a hallmark success of the civil rights movement was the Civil Rights Act, which in turn created the Equal Employment Opportunity Commission. Since the early 1970s, the EEOC has both set out criteria for and monitored compliance with the Act. When designing organizational structures and routines that would demonstrate such compliance, many firms drew on models that had originally been worked out as part of their industrial-relations policies, such as grievance procedures and

\footnotetext{
${ }^{17}$ Future work could try to gather demographic information on these establishments, for example by using EEO-1 surveys of the larger workplaces targeted by organizing campaigns (Ferguson 2015, Ferguson 2016). If for example more Civil Rights protests were associated with greater union support at establishments with more black workers, this would be evidence for more direct mechanisms of influence.
} 
routines for termination with cause. Yet organization theory has largely ignored how the preexisting normative framework of industrial jurisprudence both enabled the "rights-based" legal employment relationship and simultaneously constrained the forms that that relationship would take. While the reliance of early diversity professionals on older labor-relations policies is well understood (Edelman 1990, Edelman, Uggen \& Erlanger 1999), the spillover from those larger social movements to unions that targeted the private firm that we observe here helps us to understand why so many workers would be satisfied with managers' using those routines as a model for fair treatment in the workplace.

Similarly, the labor movement influenced firms that sought to avoid unionization. During the 1970s and 1980s, many successful American firms began experimenting with innovative policies for employee participation. The goal was to give employees a real sense of representation and voice while retaining the managerial prerogative to determine firm strategy (Kochan, Katz \& McKersie 1986). Company-dominated labor unions are illegal under the National Labor Relations Act, but affinity associations of employees around race, gender, or sexual orientation are not. Such identity-based categories, given salience by mass protest movements outside the firm, offered more progressive firms different nuclei for worker organizing and representation, separate from union control (Piore \& Safford 2006). Here we have examined the empirical evidence for osmotic mobilization of unions by the long protest wave. Given the right data, it would be equally possible (and fascinating) to model how the same protests influenced firms to support employee organizations that helped forestall unionization but that nonetheless often demanded changes to other firm policies (e.g., Briscoe \& Safford (2008)).

We should also note the empirical contribution of this study to labor-movement research and the theoretical connection it draws between that research and organizational theory. Evidence of osmotic mobilization of labor unions by movements in the long protest wave suggests that we should reconsider how effective alliances between social movements and labor unions can be for both parties. Organization theory approaches the issue by asking how worker mobilization can further movements' goals; labor-movement research approaches it by asking how social movements can revitalize the labor movement itself (Voss \& Sherman 2000, Clawson 2003, Martin 2008b). Much of the work on labor-union revitalization presumes that, if unions were able to successfully harness the energy, initiative, and popular support of social movements, they could reverse their 
historic decline. We show that there was non-trivial protest-union spillover during a period of unprecedented social upheaval and mobilization, yet this spillover was not nearly enough to change labor's fortunes. We agree that more alliances would doubtlessly help labor, and may indeed be a necessary condition of labor-union renewal, but based on these results we doubt that such efforts are a sufficient condition. Simply put, unions' partnering with social movements is not enough.

Today it is increasingly accepted that the decline of organized labor helped prime the explosion of inequality and increasing corporate power over the last generation (Levy \& Temin 2010, Western \& Rosenfeld 2011). This is the great paradox of social mobilization and organizational change in our lifetimes: the gains of rights-based, identity politics within formal organizations seemed to come at the expense of an older logic of economic- and class-based mobilization (Piore \& Safford 2006). Such is the belief that these two are substitutes, rather than complements, for one another that, in the extreme, the growth of a rights-based workplace consciousness is argued to have helped cause organized labor's decline (Lichtenstein 2002). We argue, and demonstrate, that this opposition is overstated. There was positive spillover from these outsider movements to the insiders. The patterns of mutual benefit observed among different movements, around ideological and interest overlap, can help explain when such mobilization will happen. Osmotic mobilization by itself is not enough to produce the broader types of social change for which both of these activist populations have striven for many years. Yet by beginning to theorize and explore when broad social mobilizations are more likely to produce mobilization in formal organizations, we can perhaps start to predict when opportunities might arise in the future.

\section{A Appendix: Coding of protest claims}

The $D o C A$ dataset includes the primary claims made by participants at each protest event. To code whether protests made politically progressive claims, we focused on the category of the first claim recorded. The large majority of protests made a single claim; virtually no multi-claim protest events involved progressive and conservative claims. The claim-coding scheme used in the $D o C A$ data is reproduced below.

The data also record whether the protest was "pro" or "anti" the claim in question. For many events, the stance is not recorded. We only code as progressive those where the stance toward the claim is clear. Thus for example we would record a protest as progressive if it were "pro" the Anti Nuclear (Power) Movement (claim 0200). Below we italicize a claim if the protest had to be "anti" in order to be progressive.

For testing Civil Rights protests, we focused on events with the claims flagged by an asterisk 
below. If we limit the definition to claims beginning with 1500 (Civil Rights-African Americans), our results are substantively unchanged.

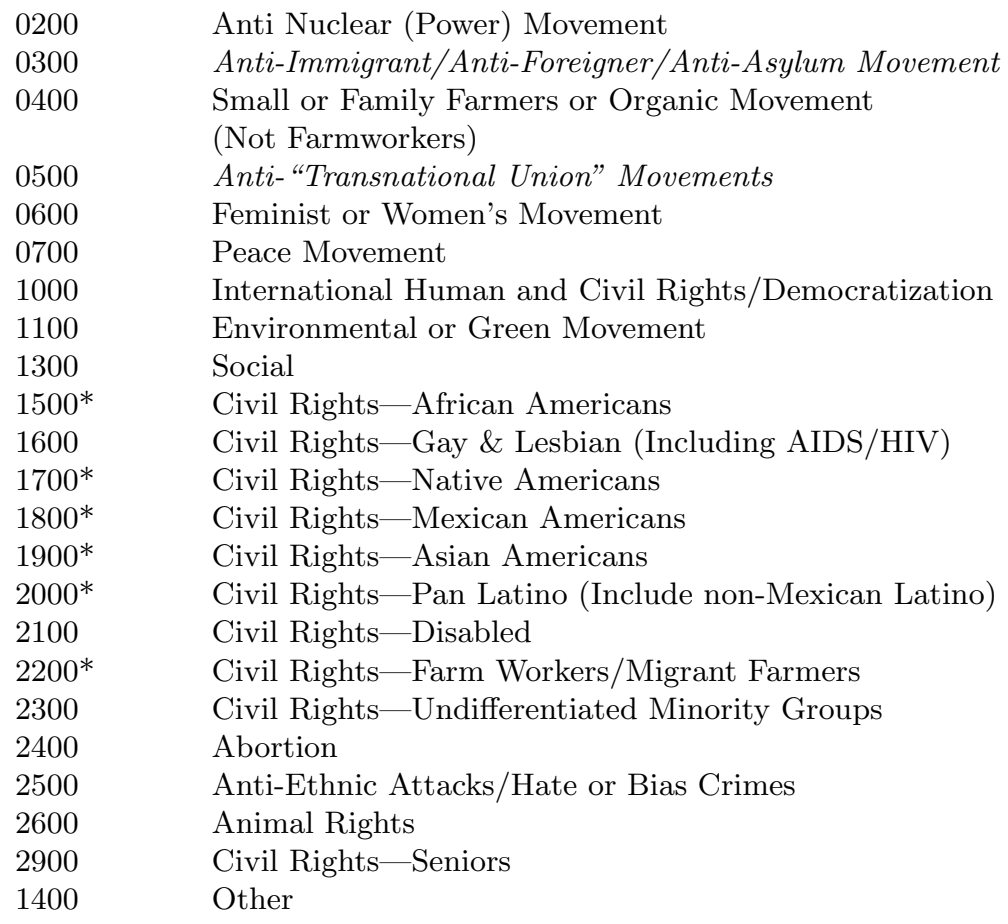

For testing women's employment-related protests, we relied on sub-claims of claim 0600, "Feminist or Women's Movement":

$0606 \quad$ Equal Pay or Comparable worth

$0607 \quad$ Gender quotas/Affirmative Action, as applied to gender

$0608 \quad$ Equal Rights Amendment (ERA)

$0610 \quad$ Anti-Discrimination in Employment

\section{B Appendix: Union names and codings}

The unions recorded in the FAST election database are listed below. For our analysis of heterogeneous effects, we wanted to differentiate unions that had particularly progressive, or conservative, relations with protest movements. We coded as progressive $(\mathrm{P})$ unions that for example co-sponsored civil rights demonstrations, lobbied Congress for equal-rights legislation, or took public stands against the Vietnam War. We coded as conservative $(\mathrm{C})$ unions that were mentioned in various works as racially exclusionary (particularly with respect to hiring and promotion policies in the building trades), or that were compromised by extensive ties to organized crime. For each union that we have coded either progressive or conservative, we have included at least one representative citation that mentions its political or criminal activities. The remaining unions we have treated as neutral (N) in our analyses.

ABG Aluminum, Brick \& Glass Workers N

ACTWU Amal. Clothing \& Textile Workers Union N 


\begin{tabular}{|c|c|c|c|}
\hline ACWA & Amal. Clothing Workers of America & $\mathrm{N}$ & \\
\hline AFGM & American Federation of Grain Millers & $\mathrm{N}$ & \\
\hline AFGW & American Flint Glass Workers & $\mathrm{N}$ & \\
\hline $\mathrm{AFT}$ & American Fed. of Teachers & $\mathrm{P}$ & (Lichtenstein 2002) \\
\hline AFTRA & American Fed. of Television \& Radio Artists & $\mathrm{N}$ & \\
\hline AFSCME & State, County \& Municipal Emps. & $\mathrm{P}$ & (Lichtenstein 2002) \\
\hline AIW & Allied Industrial Workers & $\mathrm{C}$ & (Boyle 1995) \\
\hline ALA & Alliance for Labor Action & $\mathrm{P}$ & (Lichtenstein 2002) \\
\hline ANA & American Nurses Assn. & $\mathrm{P}$ & (DeBenedetti 1990) \\
\hline $\mathrm{ATU}$ & Amalgamated Transit Union & $\mathrm{N}$ & \\
\hline AWU & Aluminum Workers Intl. Union & $\mathrm{N}$ & \\
\hline $\mathrm{BCW}$ & Bakery \& Confectionery Workers & $\mathrm{N}$ & \\
\hline BCTW & Bakery, Confectionery \& Tobacco Workers & $\mathrm{N}$ & \\
\hline BFCSD & Brewery, Flour, Cereal, Soft Drink \& Distillery & $\mathrm{C}$ & (Jacobs 2006) \\
\hline BSOIW & Bridge, Structural, \& Ornamental Iron Workers & $\mathrm{N}$ & \\
\hline CLGW & Cement, Lime, Gypsum \& Allied Workers & $\mathrm{N}$ & \\
\hline CWA & Communication Workers of America & $\mathrm{P}$ & (Clawson 2003) \\
\hline DIS50 & District 50, Allied Technical Workers & $\mathrm{P}$ & (DeBenedetti 1990) \\
\hline DWW & Distillery \& Wine Workers & $\mathrm{C}$ & (Jacobs 2006) \\
\hline GAIU & Graphic Arts Intl. Union & $\mathrm{C}$ & (James 1965, Jacobs 2006) \\
\hline GBBA & Glass Bottle Blowers Assn. & $\mathrm{N}$ & \\
\hline GCIU & Graphic Communication Intl. Union & $\mathrm{C}$ & (James 1965) \\
\hline GMPM & Molders \& Allied Workers & $\mathrm{N}$ & \\
\hline GUA & Guards Union of America & $\mathrm{N}$ & \\
\hline HERE & Hotel Emps. \& Restaurant Emps. & $\mathrm{P}$ & (Voss \& Sherman 2000) \\
\hline IAM & Intl. Assn. of Machinists & $\mathrm{N}$ & \\
\hline IATSE & Intl. Assn. of Theatrical \& Stage Emps. & $\mathrm{N}$ & \\
\hline IBB & Intl. Brotherhood of Boilermakers & $\mathrm{C}$ & (Schuwerk 1972) \\
\hline IBEW & Intl. Brotherhood of Electrical Workers & $\mathrm{C}$ & (Schatz 1983, Cowie 1999) \\
\hline IBFO & Intl. Brotherhood of Firemen \& Oilers & $\mathrm{P}$ & (Riccucci 1990) \\
\hline IBPAW & Pottery \& Allied Workers & $\mathrm{N}$ & \\
\hline IBT & Intl. Brotherhood of Teamsters & $\mathrm{P}$ & (James 1965, Ganz 2000, Berg 2003) \\
\hline ICWU & Intl. Chemical Workers Union & $\mathrm{N}$ & \\
\hline IFPTE & Intl. Fed. of Professional \& Technical Emps. & $\mathrm{N}$ & \\
\hline ILA & Intl. Longshoremens Assn. & $\mathrm{C}$ & (Jacobs 2006) \\
\hline ILGWU & Intl. Ladies Garment Workers Union & $\mathrm{N}$ & \\
\hline ILWU & Intl. Longshore \& Warehouse Union & $\mathrm{P}$ & (Lester 1974) \\
\hline ITU & Intl. Typographical Union & $\mathrm{N}$ & \\
\hline IUE & Intl. Union of Electrical Workers & $\mathrm{N}$ & \\
\hline IUMSW & Intl. Union of Marine \& Shipbuilding Workers & $\mathrm{N}$ & \\
\hline IUOE & Intl. Union of Operating Engineers & $\mathrm{C}$ & (Schuwerk 1972, Jacobs 2006) \\
\hline IWA & Intl. Woodworkers of America & $\mathrm{N}$ & \\
\hline IWIU & Insurance Workers Intl. Union & $\mathrm{C}$ & (Jacobs 2006) \\
\hline JWU & Jewelry Workers Union & $\mathrm{N}$ & \\
\hline $\mathrm{LDC}$ & Laundry \& Dry-Cleaning Workers & $\mathrm{C}$ & (James 1965, Jacobs 2006) \\
\hline LGPN & Leather Goods, Plastics, \& Novelty Workers & $\mathrm{N}$ & \\
\hline LIUNA & Laborers Intl. Union & $\mathrm{C}$ & (Jacobs 2006) \\
\hline LPIU & Lithographers \& Photoengravers Intl. Union & $\mathrm{N}$ & \\
\hline MCBW & Meat Cutter \& Butcher Workers & $\mathrm{P}$ & (Stromquist \& Bergman 1997) \\
\hline MEBA & Marine Engineers Beneficial Assn. & $\mathrm{N}$ & \\
\hline MESA & Mechanics Educational Society of America & $\mathrm{N}$ & \\
\hline MPBP & Metal Polishers, Buffers, Platers \& Helpers & $\mathrm{N}$ & \\
\hline NABET & Natl. Assn. of Broadcast Emps. \& Technicians & $\mathrm{N}$ & \\
\hline NFIU & Natl. Federation of Independent Unions & $\mathrm{C}$ & (Jacobs 2006) \\
\hline NMU & Natl. Maritime Union & $\mathrm{N}$ & \\
\hline NOITU & Natl. Org. of Independent Trade Unions & $\mathrm{C}$ & (Jacobs 2006) \\
\hline NPW & Novelty \& Production Workers & $\mathrm{C}$ & (Jacobs 2006) \\
\hline NUHHCE & Natl. Union of Hospital \& Healthcare Emps. & $\mathrm{P}$ & (Riccucci 1990) \\
\hline OCAW & Oil, Chemical \& Atomic Workers & $\mathrm{N}$ & \\
\hline
\end{tabular}




\begin{tabular}{|c|c|c|c|}
\hline OPEIU & Office \& Professional Emps. Intl. Union & $\mathrm{P}$ & (Riccucci 1990, Lichtenstein 2002) \\
\hline PAT & Painters \& Allied Trades & $\mathrm{C}$ & (Schuwerk 1972) \\
\hline PGCU & Printing \& Graphic Communications Union & $\mathrm{N}$ & \\
\hline PGOC & Plant Guard Organizing Committee & $\mathrm{N}$ & \\
\hline PGW & Plant Guard Workers of America & $\mathrm{N}$ & \\
\hline PML & Pattern Makers League & $\mathrm{N}$ & \\
\hline PSPMW & Pulp, Sulfite \& Paper Mill Workers & $\mathrm{N}$ & \\
\hline PSSEU & Production Service \& Sales Emps. & $\mathrm{N}$ & \\
\hline RCIA & Retail Clerks Intl. Assn. & $\mathrm{N}$ & \\
\hline RWAW & Roofers, Waterproofers \& Allied Workers & $\mathrm{C}$ & (Schuwerk 1972) \\
\hline RWDSU & Retail, Wholesale \& Department Store Union & $\mathrm{P}$ & (Warren \& Bronfenbrenner 2007) \\
\hline SEIU & Service Emps. Intl. Union & $\mathrm{P}$ & (Voss \& Sherman 2000) \\
\hline SFAAW & Stove, Furnace \& Allied Appliance Workers & $\mathrm{N}$ & \\
\hline $\mathrm{SIU}$ & Seafarers Intl. Union & $\mathrm{C}$ & (Schuwerk 1972) \\
\hline SMW & Sheet Metal Workers & $\mathrm{C}$ & (Schuwerk 1972) \\
\hline TCU & Transportation-Communications Union & $\mathrm{N}$ & \\
\hline TNG & The Newspaper Guild & $\mathrm{N}$ & \\
\hline TWU & Transport Workers Union & $\mathrm{P}$ & (Riccucci 1990) \\
\hline TWUA & Textile Workers Union of America & $\mathrm{N}$ & \\
\hline UA & Plumbers \& Pipefitters & $\mathrm{C}$ & (Lichtenstein 2002) \\
\hline UAW & United Auto Workers & $\mathrm{P}$ & (Boyle 1995) \\
\hline UBC & Brotherhood of Carpenters \& Joiners & $\mathrm{C}$ & (Schuwerk 1972, Lichtenstein 2002) \\
\hline $\mathrm{UE}$ & United Electrical Workers & $\mathrm{P}$ & (Schatz 1983, Milkman 1987) \\
\hline UFCW & United Food \& Commercial Workers & $\mathrm{P}$ & (Voss \& Sherman 2000) \\
\hline UFWA & United Farm Workers of America & $\mathrm{P}$ & (Ganz 2000) \\
\hline UGCW & United Glass \& Ceramic Workers & $\mathrm{N}$ & \\
\hline UIU & Upholsterers Intl. Union & $\mathrm{N}$ & \\
\hline UIWOA & United Industrial Workers of America & $\mathrm{N}$ & \\
\hline UMW & United Mine Workers & $\mathrm{N}$ & \\
\hline UNITE & Needletrades, Industrial \& Textile Emps. & $\mathrm{P}$ & (Milkman 2006) \\
\hline UPIU & United Paperworkers Intl. Union & $\mathrm{N}$ & \\
\hline UPP & United Pulp \& Paperworkers & $\mathrm{N}$ & \\
\hline UPWA & United Packinghouse, Food \& Allied Workers & $\mathrm{P}$ & (Stromquist \& Bergman 1997, Levy 1994) \\
\hline URW & United Rubber Workers & $\mathrm{N}$ & \\
\hline USW & United Steel Workers & $\mathrm{P}$ & (Nelson 2001) \\
\hline UTWA & United Textile Workers of America & $\mathrm{N}$ & \\
\hline UWA & Utility Workers Union of America & $\mathrm{N}$ & \\
\hline WA & Independent Watchmens' Assn. & $\mathrm{N}$ & \\
\hline
\end{tabular}

\section{References}

Ansari, Shahzad M., Peer C. Fiss \& Edward J. Zajac. 2010. "Made to Fit: How Practices Vary as they Diffuse." Academy of Management Review 35(1):67-92.

Banks, Andrew \& John Russo. 1999. "The Development of International Campaign-Based Network Structures: A Case Study of the IBT and ITF World Council of UPS Unions." Comparative Labor Law and Policy Journal 20(4):543-568.

Bartley, Tim \& Curtis Child. 2011. "Movements, Markets, and Fields: The Effect of Anti-Sweatshop Campaigns on U.S. Firms, 1993-2000." Social Forces 90(2):425-451.

Berg, John C., ed. 2003. Teamsters and Turtles? U.S. Progressive Political Movements in the 21st Century. Lanham, MD: Rowman \& Littlefield.

Botsch, Robert E. 1980. We Shall Not Overcome: Populism and Southern Blue-Collar Workers. Chapel Hill, NC: University of North Carolina Press.

Boyle, Kevin. 1995. The UAW and the Heyday of American Liberalism, 1945-1968. Ithaca, NY: Cornell University Press.

Briscoe, Forrest \& Abhinav Gupta. 2016. "Social Activism in and Around Organizations." Academy of Management Annals 10(1):671-727. 
Briscoe, Forrest \& Sean Safford. 2008. "The Nixon-In-China Effect: Activism, Imitation and the Institutionalization of Contentious Practices." Administrative Science Quarterly 53(3).

Clawson, Dan. 2003. The Next Upsurge: Labor and the New Social Movements. Ithaca, NY: Cornell University Press.

Clemens, Elisabeth S. 1997. The People's Lobby: Organizational Innovation and the Rise of Interest Group Politics in the United States. Chicago: University of Chicago Press.

Cohen, Philip N., Matt L. Huffman \& Stefanie Knauer. 2009. "Stalled Progress? Gender Segregation and Wage Inequality Among Managers, 1980-2000." Work and Occupations 36(4):318-342.

Cohen, Robert. 1997. When the Old Left Was Young: Student Radicals and America's First Mass Student Movement, 1929-1941. Oxford: Oxford University Press.

Conell, C. \& Kim Voss. 1990. "Formal Organization and the Fate of Social Movements: Craft Association and Class Alliance in the Knights of Labor." American Sociological Review 55:255-269.

Cooper, Alice Holmes. 1996. Paradoxes of Peace: German Peace Movements since 1945. Ann Arbor, MI: University of Michigan.

Cowie, Jefferson R. 1999. Capital Moves: RCA's Seventy-Year Quest for Cheap Labor. Ithaca, NY: ILR Press.

Craft, James A. 1991. "Unions, Bureaucracy, and Change: Old Dogs Learn New Tricks Very Slowly." Journal of Labor Research 12(4):393-405.

Cress, Daniel M. \& David A. Snow. 2000. "The Outcomes of Homeless Mobilization: The Influence of Organization, Disruption, Political Mediation, and Framing." American Journal of Sociology pp. 1063-1104.

Cumbler, John T. 1989. A Social History of Economic Decline: Business, Politics, and Work in Trenton. New Brunswick, NJ: Rutgers University Press.

Davis, Flora. 1991. Moving the Mountain: The Women's Movement in America since 1960. New York: Simon \& Schuster.

Davis, Gerald F., Calvin Morrill, Hayagreeva Rao \& Sarah A. Soule. 2008. "Introduction: Social Movements in Organizations and Markets." Administrative Science Quarterly 53:389-394.

DeBenedetti, Charles. 1990. An American Ordeal: The Antiwar Movement of the Vietnam Era. Syracuse, NY: Syracuse University Press.

Delaney, John, Paul Jarley \& Jack Fiorito. 1996. "Planning for Change: Determinants of Innovation in U.S. National Unions." Industrial and Labor Relations Review 49:597-614.

Dinlersoz, Emin, Jeremy Greenwood \& Henry Hyatt. 2014. Who do Unions Target? Unionization over the Life-Cycle of U.S. Business. Technical Report 20151 NBER.

Dobbin, Frank. 2009. Inventing Equal Opportunity. Princeton, NJ: Princeton University Press.

Dobbin, Frank \& John R. Sutton. 1998. "The Strength of a Weak State: The Rights Revolution and the Rise of Human Resource Management Divisions." American Journal of Sociology 104:441-476.

Dobbin, Frank, John Sutton, John Meyer \& W. Richard Scott. 1993. "Equal Opportunity Law and the Construction of Internal Labor Markets." American Journal of Sociology 99:396-427.

Edelman, Lauren B. 1990. "Legal Environments and Organizational Governance: The Expansion of Due Process in the American Workplace." American Journal of Sociology 95(6):1401-1440.

Edelman, Lauren B., Christopher Uggen \& Howard S. Erlanger. 1999. "The Endogeneity of Legal Regulation: Grievance Procedures as Rational Myth." American Journal of Sociology 105(2):406-454.

Epstein, Marc J. \& Karen E. Schnietz. 2002. "Measuring the Costs of Environmental and Labor Protests to Globalization: An Event Study of the Failed 1999 Seattle WTO Talks." The International Trade Journal 16(2):129-160.

Evans, Rhonda \& Tamara Kay. 2008. "How Environmentalists "Greened" Trade Policy: Strategic Action and the Architecture of Field Overlap." American Sociological Review 73(6):970-991.

Fantasia, Rick \& Kim Voss. 2004. Hard Work: Remaking the American Labor Movement. Berkeley, CA: University of California Press.

Farber, Henry S. 2001. "Union Success in Representation Elections: Why Does Unit Size Matter?" Industrial and Labor Relations Review 54(2):329-348.

Farber, Henry S. \& Bruce Western. 2001. "Accounting for the Decline of Unions in the Private Sector, 1973-1998." Journal of Labor Research 22(3):459-485. 
Farber, Henry S. \& Bruce Western. 2002. "Ronald Reagan and the Politics of Declining Union Organization." British Journal of Industrial Relations 40(3):385-401.

Ferguson, John-Paul. 2008. "The Eyes of the Needles: A Sequential Model of Union Organizing Drives, 1999-2004." Industrial and Labor Relations Review 62(1):3-21.

Ferguson, John-Paul. 2015. "The Control of Managerial Discretion: Evidence from Unionization's Impact on Employment Segregation." American Journal of Sociology 121(3):675-721.

Ferguson, John-Paul. 2016. "Racial Diversity and Union Organizing in the United States, 1999-2008." Industrial and Labor Relations Review 69(1):53-83.

Galbraith, John Kenneth. 1968. The New Industrial State. Boston: Houghton-Mifflin.

Ganz, Marshall. 2000. "Resources and Resourcefulness: Strategic Capacity in the Unionization of California Agriculture, 1959-1966." American Journal of Sociology 105(4):1003-1062.

Gelman, Andrew \& Jennifer Hill. 2007. Data Analysis Using Regression and Multilevel/Hierarchical Models. New York: Cambridge University Press.

Givan, Rebecca Kolins, Kenneth M. Roberts \& Sarah A. Soule. 2010. Introduction: The Dimensions of Diffusion. In The Diffusion of Social Movements: Actors, Mechanisms, and Political Effects, ed. Rebecca Kolins Givan, Kenneth M. Roberts \& Sarah A. Soule. New York: Cambridge University Press pp. 1-15.

Goldfield, M. 1987. The Decline of Organized Labor in the United States. Chicago: University of Chicago Press.

Greve, Henrich R. \& Hayagreeva Rao. 2012. "Echoes of the Past: Organizational Foundings as Sources of an Institutional Legacy of Mutualism." American Journal of Sociology 118(3):635-675.

Griffith, Barbara S. 1988. The Crisis of American Labor: Operation Dixie and the Defeat of the CIO. Philadelphia: Temple University Press.

Haines, Herbert H. 1984. "Black Radicalization and the Funding of Civil Rights: 1957-1970." Social Problems $32(1): 31-43$.

Hirsch, Barry T. \& David A. Macpherson. 2004. "Union Membership and Coverage Database from the Current Population Survey." Available online at http://unionstats.com.

Hirschman, Albert O. 1970. Exit, Voice, and Loyalty: Responses to Decline in Firms, Organizations, and States. Cambridge, MA: Harvard University Press.

Indivisble. 2017. "Indivisible: A Practical Guide for Resisting the Trump Agenda." https://www.indivisibleguide.com; accessed 28 February 2017.

Isaac, Larry \& Lars Christiansen. 2002. "How the Civil Rights Movement Revitalized Labor Militancy." American Sociological Review 67(5):722-746.

Isaac, Larry, Steve McDonald \& Greg Lukasik. 2006. "Takin' it from the Streets: How the Sixties Mass Movement Revitalized Unionization." American Journal of Sociology 112(1):46-96.

Jacobs, James B. 2006. Mobsters, Unions, and Feds: The Mafia and the American Labor Movement. New York: New York University Press.

James, Ralph C. 1965. Hoffa and the Teamsters: A Study of Union Power. Princeton, NJ: Van Nostrand.

Jezer, Marty. 1982. The Dark Ages: Life in the United States, 1945-1960. Cambridge, MA: South End Press.

Jung, Wooseok, Brayden King \& Sarah A. Soule. 2014. "Issue Bricolage: Explaining the Configuration of the Social Movement Sector, 1960-1995." American Journal of Sociology 120(1):187-225.

Kimeldorf, Howard \& Judith Stepan-Norris. 1992. "Historical Studies of Labor Movements in the United States." Annual Review of Sociology 18:495-517.

King, Brayden G. 2008. "A Social Movement Perspective of Stakeholder Collective Action and Influence." Business and Society 47:21-49.

King, Brayden G. \& Nicholas A. Pearce. 2010. "The Contentiousness of Markets: Politics, Social Movements, and Institutional Change in Markets." Annual Review of Sociology 36:249-267.

King, Brayden G. \& Sarah A. Soule. 2007. "Social Movements as Extra-Institutional Entrepreneurs: The Effects of Protests on Stock-Price Returns." Administrative Science Quarterly 52(3):413-442.

Kochan, Thomas, Harry Katz \& Robert McKersie. 1986. The Transformation of American Industrial Relations. Ithaca, NY: ILR Press. 
Larson, Jeff A. \& Sarah A. Soule. 2009. "Sector-Level Dynamics and Collective Action in the United States, 19651975." Mobilization: An International Quarterly 14(3):293-314.

Lester, Rubin. 1974. The Negro in the Longshore Industry. Philadelphia: University of Pennsylvania Press.

Levy, Frank \& Peter Temin. 2010. Institutions and Wages in Post-World War II America. In Labor in the Era of Globalization, ed. Clair Brown, Barry J. Eichengreen \& Michael Reich. Cambridge: Cambridge University Press pp. 15-50.

Levy, Peter B. 1994. The New Left and Labor in the 1960s. Champaign, IL: University of Illinois Press.

Lewis, Perry. 2013. Civil Disobedience: An American Tradition. New Haven, CT: Yale University Press.

Lichtenstein, Nelson. 2002. State of the Union: A Century of American Labor. Princeton, NJ: Princeton University Press.

Mansbridge, Jane J. 1986. Why We Lost the ERA. Chicago: University of Chicago Press.

Martin, Andrew W. 2008a. "The Institutional Logic of Union Organizing and the Effectiveness of Social Movement Repertoires." American Journal of Sociology 113(4):1067-1103.

Martin, Andrew W. 2008b. "Resources for Success: Social Movements, Strategic Resource Allocation, and Union Organizing Outcomes." Social Problems 55(4):501-524.

Mayer, Gerald. 2004. Union Membership Trends in the United States. Technical Report RL32553 Congressional Research Service.

McAdam, Doug. 1995. 'Initiator' and 'Spin-off' Movements: Diffusion Processes in Protest Cycles. In Repertoires and Cycles of Collective Action, ed. Mark Traugott. Durham, NC: Duke University Press pp. 217-239.

McCarthy, John D. \& Mayer N. Zald. 1977. "Resource Mobilization and Social Movements: A Partial Theory." American Journal of Sociology 82:1212-1241.

McDonnell, Mary-Hunter, Brayden G. King \& Sarah A. Soule. 2015. "A Dynamic Process Model of Private Politics: Activist Targeting and Corporate Receptivity to Social Challenges." American Sociological Review 80(3):654678.

McDonnell, Mary-Hunter \& Brayden King. 2013. "Keeping up Appearances: Reputational Threat and Impression Management after Social Movement Boycotts." Administrative Science Quarterly 58:387-419.

Meyer, David S. \& Debra C. Minkoff. 2004. "Conceptualizing Political Opportunity." Social Forces 84(4):1457-1492.

Milkman, Ruth. 1987. Gender at Work: The Dynamics of Job Segregation by Sex during World War II. Champaign, IL: University of Illinois Press.

Milkman, Ruth. 2006. L.A. Story: Immigrant Workers and the Future of the U.S. Labor Movement. New York: Russell Sage Foundation.

Miller, James. 1987. Democracy Is in the Streets: From Port Huron to the Siege of Chicago. Cambridge, MA: Harvard University Press.

Mills, C. Wright. 1967. The Sociological Imagination. New York: Oxford University Press.

Model, Jacob, Sarah A. Soule \& Brayden King. 2016. "Shareholder Activism in the United States: A Processual Approach." Working Paper.

Nelson, Bruce. 2001. Divided We Stand: American Workers and the Struggle for Black Equality. Princeton: Princeton University Press.

Olzak, Susan \& Emily Ryo. 2007. "Organizational Diversity, Vitality and Outcomes in the Civil Rights Movement." Social Forces 85(4):1561-1591.

Olzak, Susan \& S. C. Noah Uhrig. 2001. "The Ecology of Tactical Overlap.” American Sociological Review 66(5):694717.

Piore, Michael J. \& Sean Safford. 2006. "Changing Regimes of Workplace Governance, Shifting Axes of Social Mobilization, and the Challenge to Industrial Relations Theory." Industrial Relations 45(3):299-325p.

Raudenbush, Stephen W. \& Anthony S. Bryk. 2002. Hierarchical Linear Models: Applications and Data Analysis Methods. Vol. 1 of Advanced Quantitative Techniques in the Social Sciences second ed. Thousand Oaks, CA: Sage.

Riccucci, Norma. 1990. Women, Minorities, and Unions in the Public Sector. New York: Greenwood Press.

Rojas, Fabio. 2010. From Black Power to Black Studies: How a Radical Social Movement Became an Academic Discipline. Baltimore: Johns Hopkins University Press. 
Rosenfeld, Jake. 2014. What Unions No Longer Do. Cambridge, MA: Harvard University Press.

Rosenfeld, Jake \& Meredith Kleykamp. 2012. "Organized Labor and Racial Wage Inequality in the United States." American Journal of Sociology 117(5):1460-1502.

Rucht, Dieter. 1996. The Impact of National Contexts on Social Movement Structures: A Cross-Movement and Cross-National Perspective. In Comparative Perspectives on Social Movements, ed. Doug McAdam, John D. McCarthy \& Mayer Zald. Cambridge: Cambridge University Press pp. 185-204.

Schatz, Ronald W. 1983. The Electrical Workers: A History of Labor at General Electric and Westinghouse, 19231960. Chicago: University of Illinois Press.

Schuwerk, Robert P. 1972. "The Philadelphia Plan: A Study in the Dynamics of Executive Power." The University of Chicago Law Review 39(4):723-760.

Slichter, Sumner H., James J. Healy \& E. Robert Livernash. 1960. The Impact of Collective Bargaining on Management. Washington, DC: Brookings Institution.

Snow, David A. \& Robert S. Benford. 1992. Master Frames and Cycles of Protest. In Frontiers of Social Movement Theory, ed. Aldon Morris \& Carol Mueller. New Haven, CT: Yale University Press pp. 133-155.

Snow, David A. \& Sarah A. Soule. 2010. A Primer on Social Movements. Contemporary Societies Series New York: W. W. Norton \& Company.

Snow, David A., Sarah A. Soule \& Hanspeter Kriesi, eds. 2004. The Blackwell Companion to Social Movements. Oxford: Blackwell Publishing.

Soule, Sarah A. 2004. Diffusion Processes Within and Across Movements. In The Blackwell Companion to Social Movements, ed. David A. Snow, Sarah A. Soule \& Hanspeter Kriesi. Oxford: Blackwell Publishing pp. $294-310$.

Soule, Sarah A. 2009. Contention and Corporate Social Responsibility. Cambridge: Cambridge University Press.

Soule, Sarah A. 2012. "Social Movements and Markets, Industries, and Firms." Organization Studies 33(12):17151733.

Soule, Sarah A. 2013. Bringing Organizational Studies Back into Social Movement Scholarship. In The Future of Social Movement Research: Dynamics, Mechanisms, and Processes, ed. Jacquelien van Stekelenburg, Conny Roggeband \& Bert Klandermans. Minneapolis, MN: University of Minnesota Press pp. 107-124.

Soule, Sarah A., Anand Swaminathan \& Laszlo Tihanyi. 2014. "The Diffusion of Foreign Divestment from Burma." Strategic Management Journal 35(7):1032-1052.

Soule, Sarah A. \& Brayden G. King. 2008. "Competition and Resource Partitioning in Three Social Movement Industries." American Journal of Sociology 113:1568-1610.

Soule, Sarah A. \& Brayden G. King. 2015. Markets, Business, and Social Movements. In The Oxford Handbook of Social Movements, ed. Donatella della Porta \& Mario Diani. Oxford: Oxford University Press chapter 46, pp. 696-708.

Soule, Sarah A. \& Susan Olzak. 2004. "When Do Movements Matter? The Politics of Contingency and the Equal Rights Amendment." American Sociological Review 69(4):473-497.

Stromquist, Shelton \& Marvin Bergman, eds. 1997. Unionizing the Jungles: Labor and Community in the TwentiethCentury Meatpacking Industry. Iowa City, IA: University of Iowa Press.

Sugrue, Thomas J. 1996. The Origins of the Urban Crisis: Race and Inequality in Postwar Detroit. Princeton, NJ: Princeton University Press.

Tarrow, Sidney. 1989. Struggle, Politics, and Reform: Collective Action, Social Movements, and Cycles of Protest. Technical report Cornell University. Cornell Studies in International Affairs, Western Societies Papers 2.

Tarrow, Sidney. 2011. Power in Movement: Social Movements and Contentious Politics. Third ed. Cambridge: Cambridge University Press.

Taylor, Kieran Walsh. 2007. Turn to the Working Class: The New Left, Black Liberation, and the U.S. Labor Movement, 1967-1981 PhD thesis University of North Carolina at Chapel Hill.

Tilly, Charles. 1998. Popular Contention in Great Britain, 1758-1834. Cambridge, MA: Harvard University Press.

Tope, Daniel \& David Jacobs. 2009. "The Politics of Union Decline: The Contingent Determinants of Union Recognition Elections and Victories." American Sociological Review 74(5):842-864.

Troy, Leo \& Neil Sheflin. 1985. U.S. Union Sourcebook: Membership, Structure, Finance, Directory. West Orange, NJ: Industrial Relations Data and Information Services. 
Van Dyke, Nella \& Holly J. McCammon, eds. 2010. Strategic Alliances: Coalition Building and Social Movements. Minneapolis: University of Minnesota Press.

van Wijk, Jakomijn, Wouter Stam, Tom Elfring, Charlene Zietsma \& Frank den Hond. 2013. "Activists and Incumbents Structuring Change: The Interplay of Agency, Culture, and Networks in Field Evolution." Academy of Management Journal 56(2):358-386.

van Zomeren, Martin, Russell Spears, Agneta H. Fischer \& Colin Wayne Leach. 2004. "Put Your Money Where Your Mouth Is! Explaining Collective Action Tendencies Through Group-Based Anger and Group Efficacy." Journal of Personality and Social Psychology 87(5):649-664.

Vasi, Ion Bogdan \& Brayden G. King. 2012. "Social Movements, Risk Perceptions, and Economic Outcomes: The Effect of Primary and Secondary Stakeholder Activism on Firms' Perceived Environmental Risk and Financial Performance." American Sociological Review 77(4):573-596.

Voss, Kim \& Rachel Sherman. 2000. "Breaking the Iron Law of Oligarchy: Union Revitalization in the American Labor Movement." American Journal of Sociology 106(2):303-350.

Wang, Dan J. \& Sarah A. Soule. 2012. "Social Movement Organizational Collaboration: Networks of Learning and the Diffusion of Protest Tactics, 1960-1995." American Journal of Sociology 117(6):1674-1722.

Warren, Dorian \& Kate Bronfenbrenner. 2007. "Race, Gender and the Rebirth of Trade Unionism." New Labor Forum .

Western, Bruce \& Jake Rosenfeld. 2011. "Unions, Norms, and the Rise in U.S. Wage Inequality." American Sociological Review 76(4):513-537.

Whittier, Nancy. 2004. The Consequences of Social Movements for Each Other. In The Blackwell Companion to Social Movements, ed. David A. Snow \& Sarah A. Soule Hanspeter Kriesi. Blackwell Publishing pp. 531-532.

Zald, Mayer N. \& John D. McCarthy. 1980. Social Movement Industries: Cooperation and Conflict amongst Social Movement Organizations. In Research in Social Movements, Conflict, and Change, ed. Louise Kriesberg. Vol. 3 Greenwich, CT: JAI Press pp. 1-20.

Zald, Mayer N. \& Michael A. Berger. 1978. "Social Movements in Organizations: Coup d'Etat, Insurgency, and Mass Movements." American Journal of Sociology 83(4):823-861. 
Table 1: Distribution of protest events across core-based statistical areas (CBSAs), 1960-1995: Top 25 cities

\begin{tabular}{lccc}
\hline \hline CBSA & Events & $\%$ & Cum. \% \\
\hline New York-Newark-Jersey City, NY-NJ-PA & 8,203 & 39.58 & 39.58 \\
Washington-Arlington-Alexandria, DC-VA-MD & 1,967 & 9.49 & 49.07 \\
Boston-Cambridge-Newton, MA-NH & 716 & 3.45 & 52.52 \\
Chicago-Naperville-Elgin, IL-IN-WI & 662 & 3.19 & 55.71 \\
San Francisco-Oakland-Hayward, CA & 597 & 2.88 & 58.60 \\
Philadelphia-Camden-Wilmington, PA-NJ-DE & 464 & 2.24 & 60.83 \\
Los Angeles-Long Beach-Anaheim, CA & 449 & 2.17 & 63.00 \\
Atlanta-Sandy Springs-Roswell, GA & 307 & 1.48 & 64.48 \\
Trenton, NJ & 267 & 1.29 & 65.77 \\
Miami-Fort Lauderdale-West Palm Beach, FL & 210 & 1.01 & 66.78 \\
Detroit-Warren-Dearborn, MI & 205 & 0.99 & 67.77 \\
Jackson, MS & 187 & 0.90 & 68.67 \\
Birmingham-Hoover, AL & 175 & 0.84 & 69.52 \\
Albany-Schenectady-Troy, NY & 171 & 0.83 & 70.34 \\
New Haven-Milford, CT & 171 & 0.83 & 71.17 \\
Hartford-West Hartford-East Hartford, CT & 160 & 0.77 & 71.94 \\
New Orleans-Metairie, LA & 147 & 0.71 & 72.65 \\
Montgomery, AL & 125 & 0.60 & 73.25 \\
Bridgeport-Stamford-Norwalk, CT & 122 & 0.59 & 73.84 \\
Baltimore-Columbia-Towson, MD & 120 & 0.58 & 74.42 \\
Providence-Warwick, RI-MA & 114 & 0.55 & 74.97 \\
Springfield, MA & 113 & 0.55 & 75.52 \\
Pittsburgh, PA & 109 & 0.53 & 76.04 \\
St. Louis, MO-IL & 107 & 0.52 & 76.56 \\
Buffalo-Cheektowaga-Niagara Falls, NY & 104 & 0.50 & 77.06 \\
\hline \hline
\end{tabular}

Italicized CBSAs are also among the top 25 for union-organizing activity. 
Table 2: Distribution of union representation elections across core-based statistical areas (CBSAs), 1962-1998: Top 25 cities

\begin{tabular}{lccc}
\hline \hline CBSA & Elections & $\%$ & Cum. \% \\
\hline New York-Newark-Jersey City, NY-NJ-PA & 14,680 & 7.62 & 7.62 \\
Los Angeles-Long Beach-Anaheim, CA & 10,871 & 5.64 & 13.27 \\
Chicago-Naperville-Elgin, IL-IN-WI & 7,945 & 4.13 & 17.39 \\
Philadelphia-Camden-Wilmington, PA-NJ-DE & 6,633 & 3.44 & 20.83 \\
Detroit-Warren-Dearborn, MI & 6,426 & 3.34 & 24.17 \\
San Francisco-Oakland-Hayward, CA & 5,337 & 2.77 & 26.94 \\
Boston-Cambridge-Newton, MA-NH & 4,398 & 2.28 & 29.23 \\
St. Louis, MO-IL & 4,240 & 2.20 & 31.43 \\
Pittsburgh, PA & 3,591 & 1.86 & 33.29 \\
Seattle-Tacoma-Bellevue, WA & 3,552 & 1.84 & 35.14 \\
Minneapolis-St. Paul-Bloomington, MN-WI & 3,356 & 1.74 & 36.88 \\
Cleveland-Elyria, OH & 3,247 & 1.69 & 38.56 \\
Baltimore-Columbia-Towson, MD & 2,688 & 1.40 & 39.96 \\
Washington-Arlington-Alexandria, DC-VA-MD & 2,430 & 1.26 & 41.22 \\
Cincinnati, OH-KY-IN & 2,417 & 1.25 & 42.48 \\
Atlanta-Sandy Springs-Roswell, GA & 2,314 & 1.20 & 43.68 \\
Portland-Vancouver-Hillsboro, OR-WA & 2,280 & 1.18 & 44.86 \\
Dallas-Fort Worth-Arlington, TX & 2,229 & 1.16 & 46.02 \\
Kansas City, MO-KS & 2,113 & 1.10 & 47.12 \\
Milwaukee-Waukesha-West Allis, WI & 2,076 & 1.08 & 48.19 \\
Houston-The Woodlands-Sugar Land, TX & 2,049 & 1.06 & 49.26 \\
Denver-Aurora-Lakewood, CO & 1,999 & 1.04 & 50.30 \\
Indianapolis-Carmel-Anderson, IN & 1,982 & 1.03 & 51.32 \\
Buffalo-Cheektowaga-Niagara Falls, NY & 1,927 & 1.00 & 52.32 \\
Memphis, TN-MS-AR & 1,657 & 0.86 & 53.19 \\
\hline \hline
\end{tabular}

Italicized CBSAs are also among the top 25 for protest activity. 
Table 3: Distribution of union representation elections by union, 1962-1998: Top 25 most-active unions

\begin{tabular}{lccc}
\hline \hline Union & Elections & $\%$ & Cum. \% \\
\hline Teamsters (IBT) & 57,585 & 31.80 & 31.80 \\
Machinists (IAM) & 10,450 & 5.77 & 37.57 \\
Auto Workers (UAW) & 7,584 & 4.19 & 41.76 \\
Steel Workers (USW) & 6,998 & 3.86 & 45.62 \\
Service Employees (SEIU) & 6,873 & 3.80 & 49.42 \\
Electrical Workers (IBEW) & 6,643 & 3.67 & 53.09 \\
Operating Engineers (IUOE) & 5,052 & 2.79 & 55.88 \\
Hotel \& Restaurant Employees (HERE) & 4,807 & 2.65 & 58.53 \\
Retail Clerks (RCIA) & 4,447 & 2.46 & 60.99 \\
Food \& Commercial Workers (UFCW) & 4,288 & 2.37 & 63.36 \\
Carpenters \& Joiners (UBC) & 4,085 & 2.26 & 65.61 \\
Meat Cutters \& Butchers (MCBW) & 3,312 & 1.83 & 67.44 \\
Laborers (LIUNA) & 3,064 & 1.69 & 69.13 \\
Retail, Wholesale \& Dept. Store (RWDSU) & 2,832 & 1.56 & 70.70 \\
Communication Workers (CWA) & 2,593 & 1.43 & 72.13 \\
Oil, Chemical \& Atomic Workers (OCAW) & 2,155 & 1.19 & 73.32 \\
Sheet Metal Workers (SMW) & 2,128 & 1.18 & 74.49 \\
Electrial Equipment Workers (IUE) & 2,029 & 1.12 & 75.61 \\
Bakery, Confectionary \& Tobacco (BCTW) & 1,907 & 1.05 & 76.67 \\
Printing \& Graphic Communication (PGCU) & 1,846 & 1.02 & 77.69 \\
Office \& Professional Employees (OPEIU) & 1,775 & 0.98 & 78.67 \\
Painters (PAT) & 1,521 & 0.84 & 79.51 \\
Iron Workers (BSOIW) & 1,424 & 0.79 & 80.29 \\
District 50 (DIS50) & 1,229 & 0.68 & 80.97 \\
Graphic Artists (GAIU) & 1,169 & 0.65 & 81.62 \\
\hline \hline
\end{tabular}

We list the full names for all unions discussed in the text in the appendix. 
Table 4: Summary statistics

\begin{tabular}{lcccc}
\hline \hline & Mean & S.D. & Min & Max \\
\hline Vote share & 0.502 & 0.229 & 0.004 & 0.999 \\
$\ln$ (Lagged protests) & 1.008 & 1.545 & 0.000 & 7.266 \\
$\ln$ (Median protest size) & 2.366 & 2.947 & -0.223 & 9.136 \\
$\ln$ (Election-unit size) & 3.412 & 1.166 & 0.693 & 9.877 \\
Incumbent on ballot & 0.772 & 0.420 & 0.000 & 1.000 \\
ln(Lagged strikes) & 6.195 & 1.457 & 0.000 & 8.231 \\
Conservative politics & 0.521 & 0.088 & 0.000 & 0.975 \\
State union density & 24.698 & 8.587 & 3.300 & 43.300 \\
State unemployment (\%) & 4.234 & 3.678 & 0.020 & 17.400 \\
Share in manufacturing & 0.101 & 0.042 & 0.000 & 0.332 \\
CBSA population & 14.269 & 1.417 & 9.516 & 16.739 \\
CBSA share black & 0.118 & 0.080 & 0.000 & 0.484 \\
\hline Observations & \multicolumn{5}{c}{130653} \\
\hline \hline
\end{tabular}


Table 5: Bivariate correlations

\begin{tabular}{lcccccc}
\hline \hline & $(1)$ & $(2)$ & $(3)$ & $(4)$ & $(5)$ & $(6)$ \\
\hline (1) Vote share & 1.00 & & & & & \\
(2) $\ln$ (Lagged protests) & 0.03 & 1.00 & & & & \\
(3) $\ln$ (Median protest size) & 0.03 & 0.85 & 1.00 & & & \\
(4) $\ln$ (Election-unit size) & -0.06 & -0.03 & -0.04 & 1.00 & & \\
(5) Incumbent on ballot & 0.03 & 0.08 & 0.07 & -0.02 & 1.00 & \\
(6) Conservative politics & -0.03 & -0.07 & -0.03 & 0.05 & 0.03 & 1.00 \\
(7) State union density & 0.05 & 0.09 & 0.04 & -0.08 & 0.26 & -0.19 \\
(8) State unemployment (\%) & -0.08 & -0.08 & -0.06 & -0.01 & -0.34 & -0.12 \\
(9) Share in manufacturing & -0.02 & -0.08 & -0.07 & 0.02 & -0.01 & 0.12 \\
(10) CBSA population & 0.01 & 0.34 & 0.25 & -0.02 & 0.05 & -0.30 \\
(11) CBSA share black & 0.00 & 0.23 & 0.18 & 0.07 & 0.01 & 0.01 \\
(12) ln(Lagged strikes) & 0.03 & 0.10 & 0.05 & -0.05 & 0.25 & -0.04 \\
& & & & & & \\
& $(7)$ & $(8)$ & $(9)$ & $(10)$ & $(11)$ & $(12)$ \\
\hline (7) State union density & 1.00 & & & & & \\
(8) State unemployment (\%) & -0.26 & 1.00 & & & & \\
(9) Share in manufacturing & 0.26 & 0.06 & 1.00 & & & \\
(10) CBSA population & 0.21 & 0.01 & -0.09 & 1.00 & & \\
(11) CBSA share black & -0.20 & 0.02 & -0.11 & 0.35 & 1.00 & \\
(12) ln(Lagged strikes) & 0.68 & -0.19 & 0.30 & 0.23 & -0.09 & 1.00 \\
\hline \hline
\end{tabular}


Table 6: General linear models of vote share in union-representation elections

\begin{tabular}{|c|c|c|c|c|}
\hline & $(1)$ & $(2)$ & $(3)$ & $(4)$ \\
\hline $\ln$ (Lagged protests) & $\begin{array}{l}0.020^{* *} \\
(0.002)\end{array}$ & $\begin{array}{c}0.031^{* * *} \\
(0.006)\end{array}$ & $\begin{array}{l}0.018^{* *} \\
(0.003)\end{array}$ & $\begin{array}{l}0.013^{* *} \\
(0.003)\end{array}$ \\
\hline $\ln$ (Median protest size) & & $\begin{array}{c}-0.006^{* *} \\
(0.002)\end{array}$ & & \\
\hline $\ln ($ Election-unit size $)$ & & & $\begin{array}{c}-0.045^{* *} \\
(0.014)\end{array}$ & $\begin{array}{c}-0.043^{* *} \\
(0.015)\end{array}$ \\
\hline Incumbent on ballot & & & $\begin{array}{c}0.050^{* *} \\
(0.014)\end{array}$ & $\begin{array}{l}-0.025^{*} \\
(0.011)\end{array}$ \\
\hline $\ln$ (Lagged strikes) & & & & $\begin{array}{l}-0.000 \\
(0.004)\end{array}$ \\
\hline Conservative politics & & & & $\begin{array}{c}-0.378^{* *} \\
(0.051)\end{array}$ \\
\hline State union density & & & & $\begin{array}{l}0.004^{* *} \\
(0.001)\end{array}$ \\
\hline State unemployment (\%) & & & & $\begin{array}{c}-0.021^{* *} \\
(0.003)\end{array}$ \\
\hline Share in manufacturing & & & & $\begin{array}{c}-0.456^{* *} \\
(0.087)\end{array}$ \\
\hline CBSA population & & & & $\begin{array}{l}-0.012^{*} \\
(0.005)\end{array}$ \\
\hline CBSA share black & & & & $\begin{array}{l}0.182^{* *} \\
(0.061)\end{array}$ \\
\hline Observations & 130653 & 51362 & 130651 & 130651 \\
\hline Log-likelihood & -65477.75 & -25800.59 & -65424.01 & -65302.12 \\
\hline
\end{tabular}

Standard errors in parentheses

Standard errors are clustered by CBSA and year

$+p<.10,{ }^{*} p<.05,{ }^{* *} p<.01$ 
Table 7: General linear models of vote share in union-representation elections with fixed effects

\begin{tabular}{|c|c|c|c|c|c|c|}
\hline & (5) & (6) & (7) & $(8)$ & $\overline{(9)}$ & $(10)$ \\
\hline \multirow{2}{*}{$\ln$ (Lagged protests) } & $0.013^{* *}$ & $0.014^{* *}$ & $0.010^{* *}$ & $0.013^{* *}$ & $0.010^{* *}$ & $0.008^{* *}$ \\
\hline & $(0.003)$ & $(0.002)$ & $(0.003)$ & $(0.003)$ & $(0.002)$ & $(0.003)$ \\
\hline Year fixed effects & $\mathrm{Y}$ & $\mathrm{N}$ & $\mathrm{N}$ & $\mathrm{Y}$ & $\mathrm{N}$ & Y \\
\hline CBSA fixed effects & $\mathrm{N}$ & $\mathrm{Y}$ & $\mathrm{N}$ & $\mathrm{Y}$ & Y & $\mathrm{N}$ \\
\hline Union fixed effects & $\mathrm{N}$ & $\mathrm{N}$ & $\mathrm{Y}$ & $\mathrm{N}$ & $\mathrm{Y}$ & $\mathrm{Y}$ \\
\hline \multirow[t]{2}{*}{$\overline{\ln }(\overline{\text { Election-unit size })}$} & $-\overline{-0.04} \overline{5}^{* \bar{*}}$ & $-\overline{-0.04} \overline{3}^{* \bar{*}}$ & $-\overline{-0.063^{* *}}$ & $-\overline{0.043^{* *}}{ }^{-}$ & $-\overline{0} . \overline{0} \overline{2}^{\bar{*} *}$ & $-\overline{0} . \overline{0} 65^{\bar{*} *}$ \\
\hline & $(0.015)$ & $(0.015)$ & $(0.014)$ & $(0.015)$ & $(0.014)$ & $(0.014)$ \\
\hline \multirow[t]{2}{*}{ Incumbent on ballot } & $-0.045^{* *}$ & $-0.039^{* *}$ & $-0.024^{*}$ & $-0.056^{* *}$ & $-0.038^{* *}$ & $-0.048^{* *}$ \\
\hline & $(0.012)$ & $(0.012)$ & $(0.011)$ & $(0.011)$ & $(0.012)$ & $(0.011)$ \\
\hline \multirow[t]{2}{*}{ ln(Lagged strikes) } & 0.004 & $-0.032^{* *}$ & 0.004 & $-0.017^{* *}$ & $-0.029^{* *}$ & 0.005 \\
\hline & $(0.004)$ & $(0.005)$ & $(0.004)$ & $(0.005)$ & $(0.004)$ & $(0.004)$ \\
\hline \multirow[t]{2}{*}{ Conservative politics } & $-0.352^{* *}$ & $-0.342^{* *}$ & $-0.332^{* *}$ & -0.165 & $-0.342^{* *}$ & $-0.302^{* *}$ \\
\hline & $(0.058)$ & $(0.059)$ & $(0.040)$ & $(0.102)$ & $(0.054)$ & $(0.040)$ \\
\hline \multirow[t]{2}{*}{ State union density } & $0.002^{+}$ & $0.009^{* *}$ & $0.002^{* *}$ & $0.003^{*}$ & $0.009^{* *}$ & -0.000 \\
\hline & $(0.001)$ & $(0.002)$ & $(0.001)$ & $(0.002)$ & $(0.001)$ & $(0.001)$ \\
\hline \multirow[t]{2}{*}{ State unemployment (\%) } & -0.003 & $-0.017^{* *}$ & $-0.023^{* *}$ & -0.001 & $-0.018^{* *}$ & -0.003 \\
\hline & $(0.002)$ & $(0.002)$ & $(0.002)$ & $(0.002)$ & $(0.001)$ & $(0.002)$ \\
\hline \multirow[t]{2}{*}{ Share in manufacturing } & $-0.254^{* *}$ & $-0.483^{* *}$ & $-0.494^{* *}$ & $-0.259^{* *}$ & $-0.487^{* *}$ & $-0.270^{* *}$ \\
\hline & $(0.093)$ & $(0.106)$ & $(0.068)$ & $(0.097)$ & $(0.092)$ & $(0.079)$ \\
\hline \multirow[t]{2}{*}{ CBSA population } & $-0.007^{+}$ & $-0.117^{* *}$ & $-0.015^{* *}$ & 0.049 & $-0.137^{* *}$ & $-0.009^{* *}$ \\
\hline & $(0.004)$ & $(0.036)$ & $(0.003)$ & $(0.041)$ & $(0.030)$ & $(0.003)$ \\
\hline \multirow[t]{2}{*}{ CBSA share black } & $0.119^{*}$ & -0.239 & $0.117^{*}$ & $1.184^{* *}$ & -0.572 & 0.047 \\
\hline & $(0.060)$ & $(0.412)$ & $(0.049)$ & $(0.420)$ & $(0.387)$ & $(0.051)$ \\
\hline Observations & 130651 & 130651 & 130651 & 130651 & 130651 & 130651 \\
\hline Log-likelihood & -65255.93 & -65193.96 & -64994.87 & -65156.61 & -64895.80 & -64942.89 \\
\hline Model d.f. & 43 & 200 & 13 & 205 & 184 & 47 \\
\hline
\end{tabular}

Standard errors in parentheses

Standard errors are clustered by CBSA and year

${ }^{+} p<.10,{ }^{*} p<.05,{ }^{* *} p<.01$ 
Table 8: General linear models of vote share in union-representation elections, focusing on progressive, civil-rights, and women's employment-related protests

\begin{tabular}{|c|c|c|c|c|c|}
\hline & $\begin{array}{c}(11) \\
\text { Progressive } \\
\text { protests }\end{array}$ & $\begin{array}{c}(12) \\
\text { Civil-Rights } \\
\text { protests, } \\
1965-1981\end{array}$ & $\begin{array}{c}(13) \\
\text { Civil-Rights } \\
\text { protests, } \\
1982-2000\end{array}$ & $\begin{array}{c}(14) \\
\text { Women's } \\
\text { protests, } \\
1965-1981\end{array}$ & $\begin{array}{c}(15) \\
\text { Women's } \\
\text { protests, } \\
1982-2000\end{array}$ \\
\hline $\ln$ (Lagged progressive protests) & $\begin{array}{l}0.015^{* *} \\
(0.003)\end{array}$ & & & & \\
\hline $\ln$ (Lagged civil-rights protests) & & $\begin{array}{l}0.042^{* *} \\
(0.006)\end{array}$ & $\begin{array}{l}0.014^{* *} \\
(0.004)\end{array}$ & & \\
\hline $\ln$ (Lagged women's protests) & & & & $\begin{array}{c}0.033^{*} \\
(0.014)\end{array}$ & $\begin{array}{l}0.081^{* *} \\
(0.016)\end{array}$ \\
\hline $\ln ($ Election-unit size $)$ & $\begin{array}{c}-0.044^{* *} \\
(0.015)\end{array}$ & $\begin{array}{l}-0.039^{*} \\
(0.017)\end{array}$ & $\begin{array}{c}-0.046^{* *} \\
(0.014)\end{array}$ & $\begin{array}{c}-0.046^{* *} \\
(0.014)\end{array}$ & $\begin{array}{l}-0.040^{*} \\
(0.017)\end{array}$ \\
\hline Incumbent on ballot & $\begin{array}{l}-0.026^{*} \\
(0.011)\end{array}$ & $\begin{array}{c}-0.043^{* *} \\
(0.012)\end{array}$ & $\begin{array}{l}-0.009 \\
(0.018)\end{array}$ & $\begin{array}{l}-0.008 \\
(0.018)\end{array}$ & $\begin{array}{c}-0.042^{* *} \\
(0.012)\end{array}$ \\
\hline $\ln$ (Lagged strikes) & $\begin{array}{l}-0.000 \\
(0.004)\end{array}$ & $\begin{array}{r}-0.007^{+} \\
(0.004)\end{array}$ & $\begin{array}{c}0.005 \\
(0.006)\end{array}$ & $\begin{array}{c}0.004 \\
(0.006)\end{array}$ & $\begin{array}{l}-0.006 \\
(0.004)\end{array}$ \\
\hline Conservative politics & $\begin{array}{c}-0.376^{* *} \\
(0.051)\end{array}$ & $\begin{array}{c}-0.414^{* *} \\
(0.097)\end{array}$ & $\begin{array}{c}-0.404^{* *} \\
(0.044)\end{array}$ & $\begin{array}{c}-0.405^{* *} \\
(0.044)\end{array}$ & $\begin{array}{c}-0.431^{* *} \\
(0.097)\end{array}$ \\
\hline State union density (\%) & $\begin{array}{l}0.003^{* *} \\
(0.001)\end{array}$ & $\begin{array}{c}0.002 \\
(0.001)\end{array}$ & $\begin{array}{l}0.003^{* *} \\
(0.001)\end{array}$ & $\begin{array}{l}0.003^{* *} \\
(0.001)\end{array}$ & $\begin{array}{c}0.002 \\
(0.001)\end{array}$ \\
\hline State unemployment (\%) & $\begin{array}{c}-0.020^{* *} \\
(0.003)\end{array}$ & $\begin{array}{l}-0.010^{*} \\
(0.004)\end{array}$ & $\begin{array}{c}-0.022^{* *} \\
(0.003)\end{array}$ & $\begin{array}{c}-0.023^{* *} \\
(0.003)\end{array}$ & $\begin{array}{l}-0.010^{*} \\
(0.004)\end{array}$ \\
\hline Share in manufacturing & $\begin{array}{c}-0.456^{* *} \\
(0.087)\end{array}$ & $\begin{array}{c}-0.450^{*} \\
(0.202)\end{array}$ & $\begin{array}{c}-0.424^{* *} \\
(0.088)\end{array}$ & $\begin{array}{c}-0.443^{* *} \\
(0.089)\end{array}$ & $\begin{array}{c}-0.440^{*} \\
(0.200)\end{array}$ \\
\hline CBSA population & $\begin{array}{l}-0.012^{*} \\
(0.005)\end{array}$ & $\begin{array}{l}-0.006 \\
(0.006)\end{array}$ & $\begin{array}{c}-0.014^{* *} \\
(0.004)\end{array}$ & $\begin{array}{c}-0.013^{* *} \\
(0.004)\end{array}$ & $\begin{array}{l}-0.004 \\
(0.006)\end{array}$ \\
\hline CBSA share black & $\begin{array}{l}0.183^{* *} \\
(0.061)\end{array}$ & $\begin{array}{c}0.115 \\
(0.084)\end{array}$ & $\begin{array}{l}0.174^{* *} \\
(0.062)\end{array}$ & $\begin{array}{l}0.209^{* *} \\
(0.061)\end{array}$ & $\begin{array}{c}0.131 \\
(0.084)\end{array}$ \\
\hline $\begin{array}{l}\text { Observations } \\
\text { Log-likelihood }\end{array}$ & $\begin{array}{c}130651 \\
-65302.25\end{array}$ & $\begin{array}{c}83484 \\
-41728.43\end{array}$ & $\begin{array}{c}47167 \\
-23566.68\end{array}$ & $\begin{array}{c}83484 \\
-41729.32\end{array}$ & $\begin{array}{c}47167 \\
-23568.38\end{array}$ \\
\hline
\end{tabular}

Standard errors in parentheses

Standard errors are clustered by CBSA and year

${ }^{+} p<.10,{ }^{*} p<.05,{ }^{* *} p<.01$ 
Table 9: General linear models of vote share in union-representation elections, excluding several sources of confounding variation

\begin{tabular}{|c|c|c|c|}
\hline & $\begin{array}{c}(16) \\
\text { Excluding } \\
\text { NYC }\end{array}$ & $\begin{array}{c}\text { (17) } \\
\text { Excluding } \\
\text { Teamsters }\end{array}$ & $\begin{array}{c}\text { (18) } \\
\text { Excluding } \\
1982-1999\end{array}$ \\
\hline $\ln$ (Lagged protests) & $\begin{array}{l}0.014^{* *} \\
(0.003)\end{array}$ & $\begin{array}{c}0.012^{* *} \\
(0.003)\end{array}$ & $\begin{array}{l}0.032^{* *} \\
(0.004)\end{array}$ \\
\hline $\ln ($ Election-unit size $)$ & $\begin{array}{c}-0.050^{* *} \\
(0.013)\end{array}$ & $\begin{array}{c}-0.041^{*} \\
(0.017)\end{array}$ & $\begin{array}{c}-0.039^{*} \\
(0.017)\end{array}$ \\
\hline Incumbent on ballot & $\begin{array}{c}-0.028^{*} \\
(0.011)\end{array}$ & $\begin{array}{r}-0.025^{+} \\
(0.015)\end{array}$ & $\begin{array}{c}-0.043^{* *} \\
(0.012)\end{array}$ \\
\hline $\ln$ (Lagged strikes) & $\begin{array}{c}0.000 \\
(0.004)\end{array}$ & $\begin{array}{l}-0.004 \\
(0.005)\end{array}$ & $\begin{array}{l}-0.006 \\
(0.004)\end{array}$ \\
\hline Conservative politics & $\begin{array}{c}-0.389^{* *} \\
(0.052)\end{array}$ & $\begin{array}{c}-0.377^{* *} \\
(0.068)\end{array}$ & $\begin{array}{c}-0.418^{* *} \\
(0.098)\end{array}$ \\
\hline State union density & $\begin{array}{l}0.003^{* *} \\
(0.001)\end{array}$ & $\begin{array}{l}0.003^{* *} \\
(0.001)\end{array}$ & $\begin{array}{c}0.002 \\
(0.001)\end{array}$ \\
\hline State unemployment (\%) & $\begin{array}{c}-0.021^{* *} \\
(0.003)\end{array}$ & $\begin{array}{c}-0.018^{* *} \\
(0.003)\end{array}$ & $\begin{array}{c}-0.010^{* *} \\
(0.004)\end{array}$ \\
\hline Share in manufacturing & $\begin{array}{c}-0.373^{* *} \\
(0.094)\end{array}$ & $\begin{array}{c}-0.476^{* *} \\
(0.117)\end{array}$ & $\begin{array}{l}-0.422^{*} \\
(0.203)\end{array}$ \\
\hline CBSA population & $\begin{array}{c}-0.017^{* *} \\
(0.004)\end{array}$ & $\begin{array}{l}-0.005 \\
(0.005)\end{array}$ & $\begin{array}{l}-0.009 \\
(0.006)\end{array}$ \\
\hline CBSA share black & $\begin{array}{l}0.176^{* *} \\
(0.063)\end{array}$ & $\begin{array}{l}0.177^{*} \\
(0.088)\end{array}$ & $\begin{array}{c}0.126 \\
(0.084)\end{array}$ \\
\hline $\begin{array}{l}\text { Observations } \\
\text { Log-likelihood }\end{array}$ & $\begin{array}{c}120697 \\
-60219.46\end{array}$ & $\begin{array}{c}90045 \\
-45048.25\end{array}$ & $\begin{array}{c}82484 \\
-38562.61\end{array}$ \\
\hline
\end{tabular}


Table 10: Comparison of alternative specification of vote share and alternative model specifications

\begin{tabular}{lccc}
\hline \hline & $\begin{array}{c}(19) \\
\text { Non-trimmed } \\
\text { vote share }\end{array}$ & OLS & $\begin{array}{c}(21) \\
\text { Logit } \\
\text { Win/loss }\end{array}$ \\
\hline ln(Lagged protests) & $0.016^{* *}$ & $0.030^{* *}$ & $0.021^{* *}$ \\
& $(0.004)$ & $(0.001)$ & $(0.005)$ \\
$\ln$ (Election-unit size) & -0.080 & $-0.011^{* *}$ & $-0.099^{* *}$ \\
& $(0.067)$ & $(0.004)$ & $(0.022)$ \\
Incumbent on ballot & $-0.109^{* *}$ & $-0.006^{*}$ & -0.013 \\
& $(0.019)$ & $(0.003)$ & $(0.020)$ \\
ln(Lagged strikes) & -0.012 & -0.000 & 0.001 \\
& $(0.010)$ & $(0.001)$ & $(0.010)$ \\
Conservative politics & $-0.522^{* *}$ & $-0.094^{* *}$ & $-0.721^{* *}$ \\
& $(0.063)$ & $(0.013)$ & $(0.098)$ \\
State union density & $0.007^{* *}$ & $0.001^{* *}$ & $0.004^{* *}$ \\
& $(0.002)$ & $(0.000)$ & $(0.002)$ \\
State unemployment $(\%)$ & $-0.036^{* *}$ & $-0.005^{* *}$ & $-0.039^{* *}$ \\
Share in manufacturing & $(0.005)$ & $(0.001)$ & $(0.005)$ \\
& $-0.632^{* *}$ & $-0.113^{* *}$ & $-0.872^{* *}$ \\
CBSA population & $(0.192)$ & $(0.022)$ & $(0.175)$ \\
& $-0.014^{* *}$ & $-0.003^{*}$ & $-0.020^{* *}$ \\
CBSA share black & $(0.005)$ & $(0.001)$ & $(0.007)$ \\
& $0.256^{* *}$ & $0.045^{* *}$ & $0.344^{*}$ \\
Observations & $(0.076)$ & $(0.015)$ & $(0.137)$ \\
\hline Log-likelihood & 157243 & 130651 & 130651 \\
\hline \hline & -83014.52 & 8188.45 & -89308.14 \\
\hline
\end{tabular}

Standard errors in parentheses

Standard errors are clustered by CBSA and year

${ }^{+} p<.10,{ }^{*} p<.05,{ }^{* *} p<.01$ 
Table 11: ANOVA from hierarchical linear models, testing whether heterogeneity in protest effects by union improves model fit

\begin{tabular}{l|ccc}
\hline \hline & AIC & log-likelihood & $\chi^{2}$ \\
Union intercepts & -14384 & 7194.8 & \\
Union intercepts; union slopes & -14421 & 7215.4 & $41.17^{* *}$ \\
City, year, \& union intercepts & -16278 & 8252.1 & \\
City, year, \& union intercepts; union slopes & -16308 & 8268.8 & $33.50^{* *}$ \\
\hline \hline
\end{tabular}

${ }^{+} p<.10,{ }^{*} p<.05,{ }^{* *} p<.01$ 


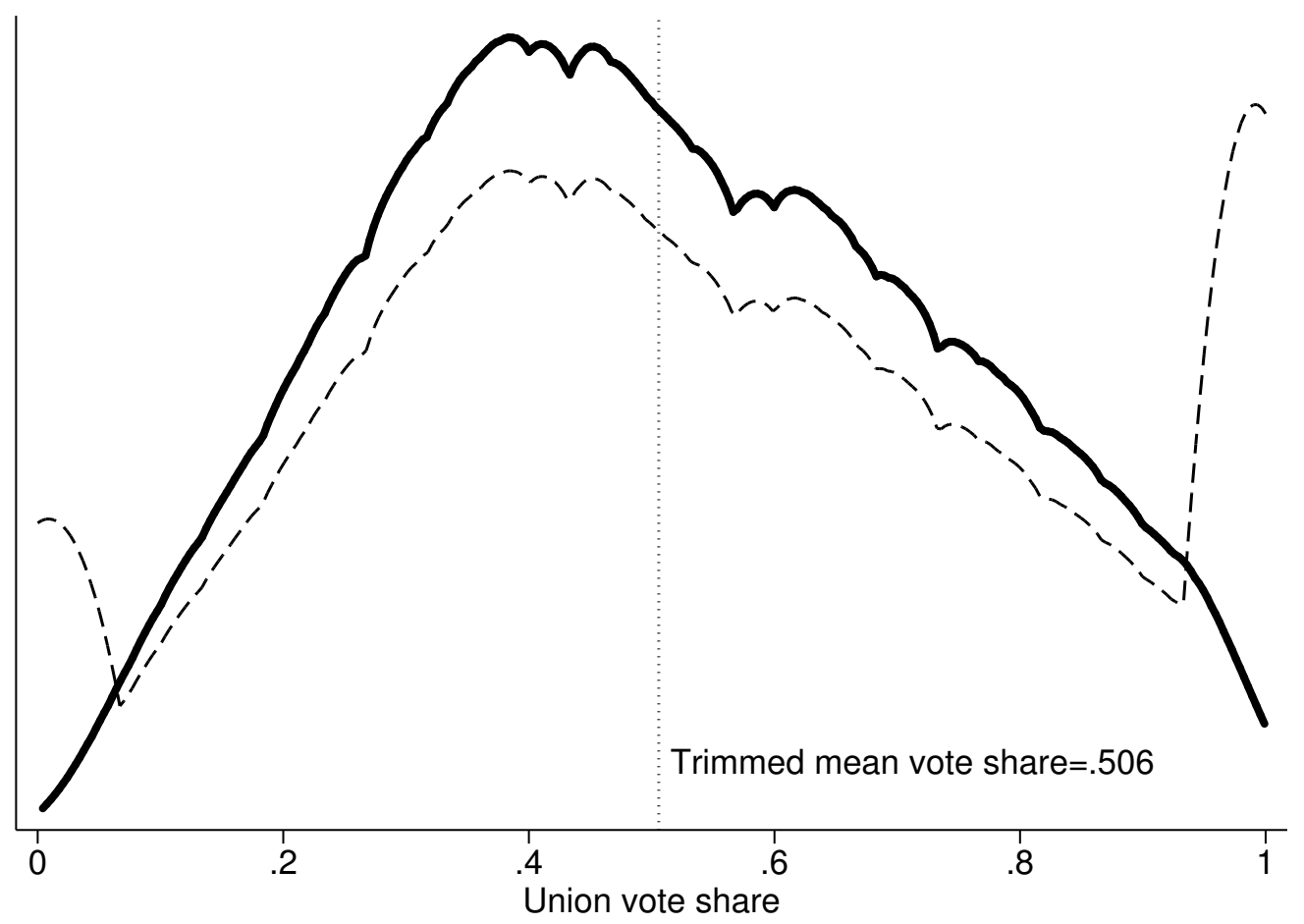

Figure 1: Kernel-density plots of the distribution of union vote shares in union-certification elections (dashed line), and the "trimmed" distribution where vote share lies between 0 and 1. 


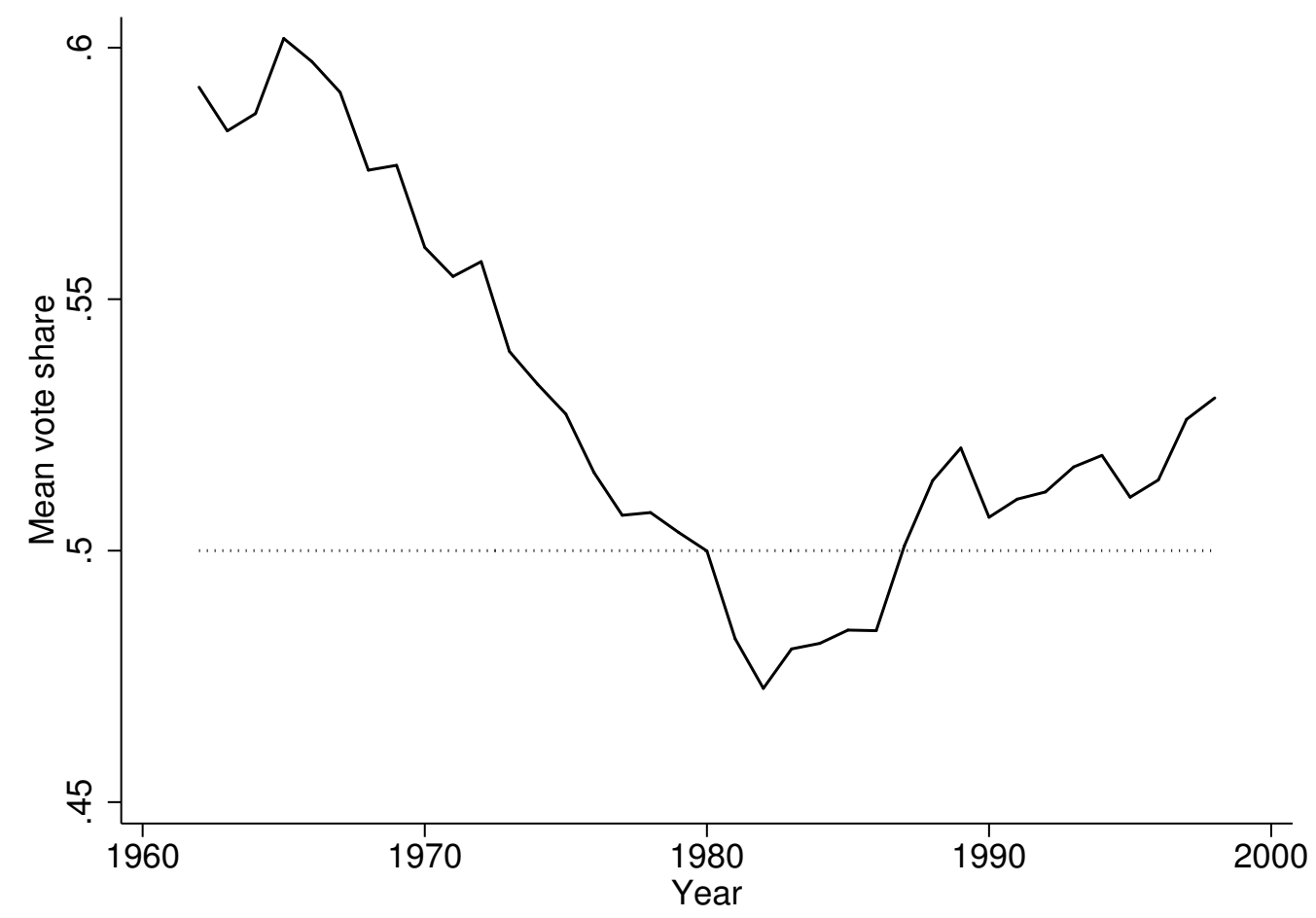

Figure 2: Average vote share received by the union in representation elections, by year 


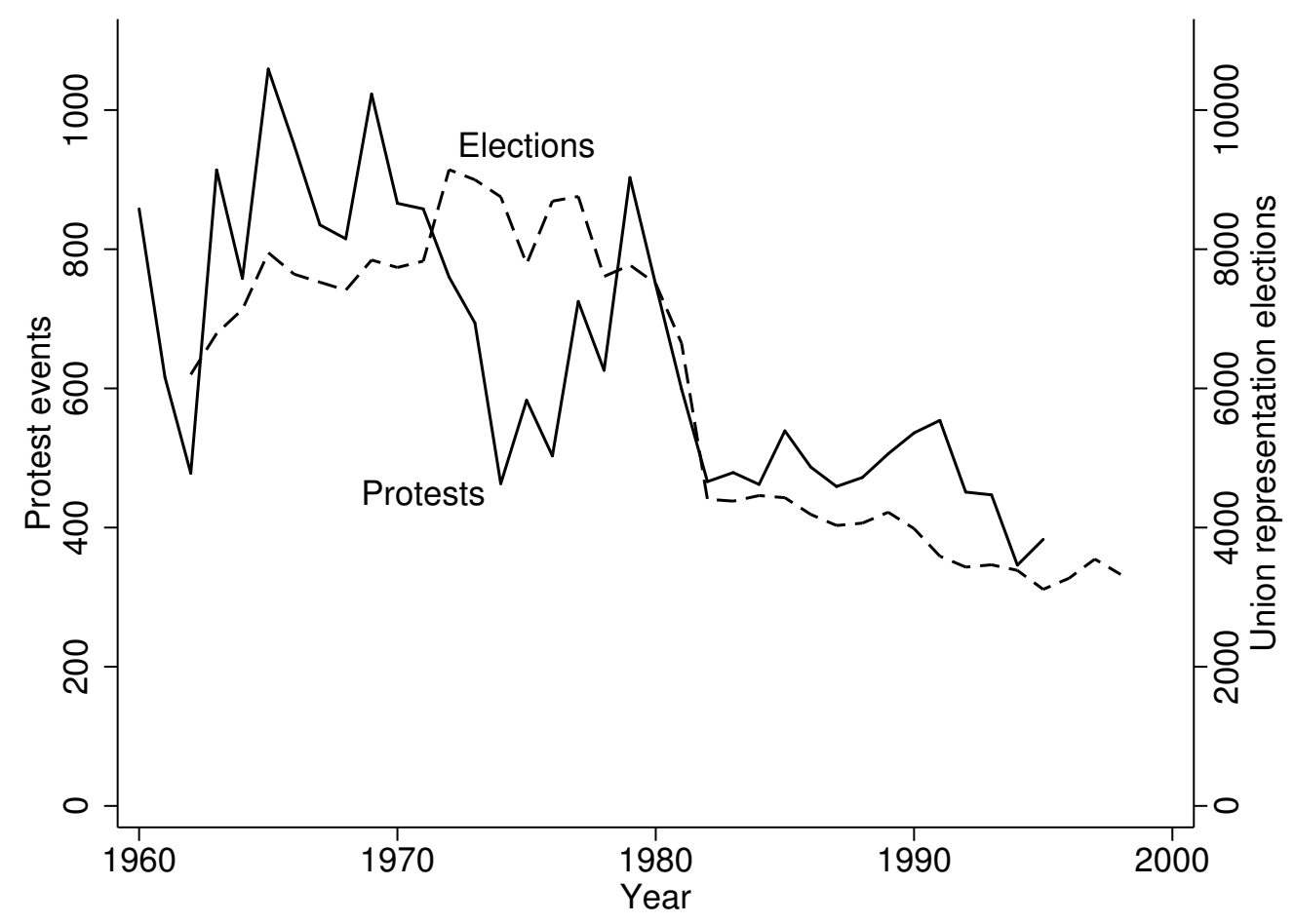

Figure 3: Protest activity and union-representation elections, per year 


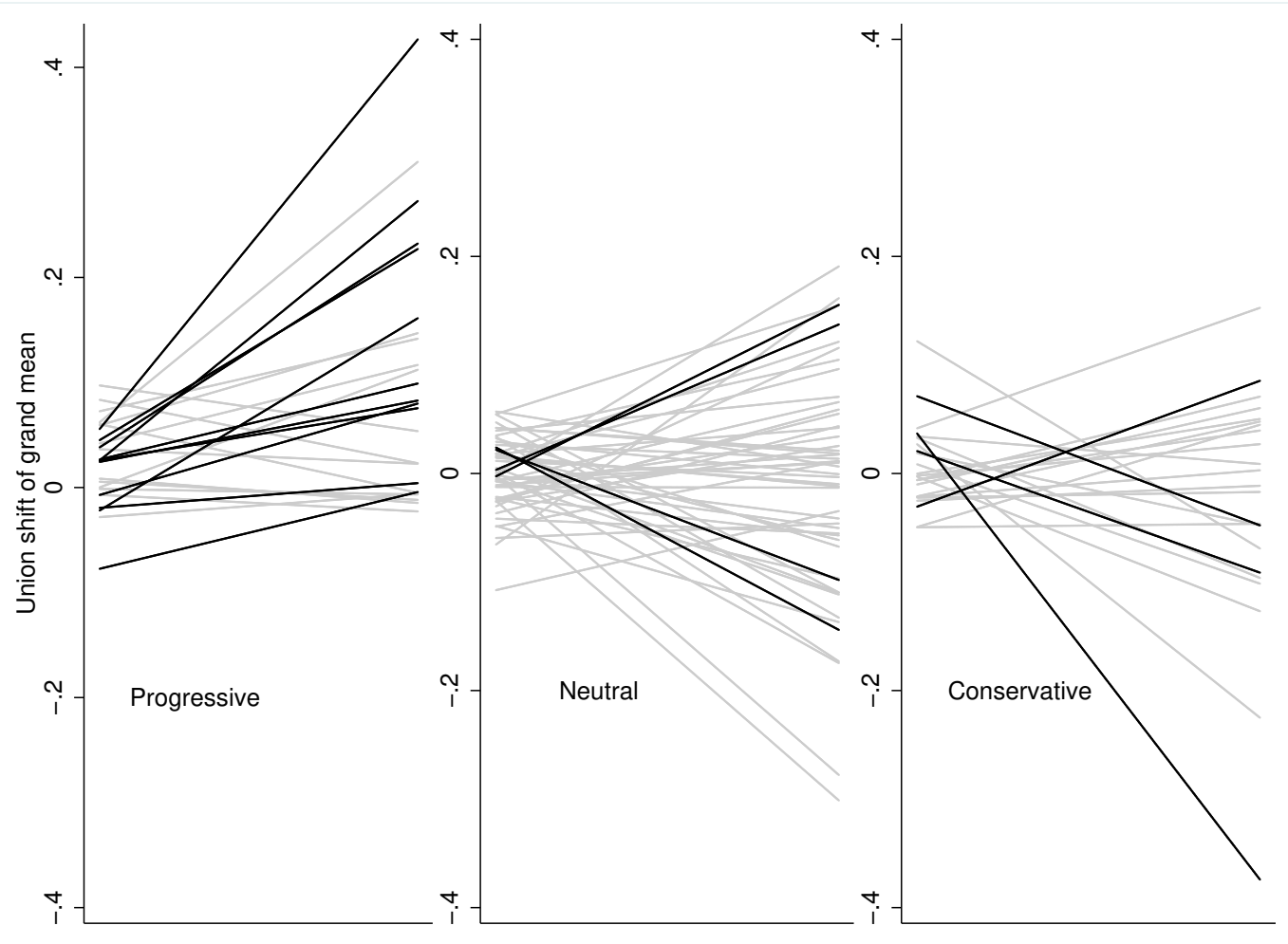

Figure 4: Heterogeneity of effect size of protest on union vote share, shown for different unions. Each line shows the slope and intercept for one union. Faded lines are not statistically significant. Unions are grouped by political stance, as described in the text and appendix B.

$\begin{array}{rlr} & \text { Mean effect } & \text { Share of org } \\ \text { Progressive } & .014^{* *} & 52.6 \\ \text { Neutral } & .004 & 33.1 \\ \text { Conservative } & -.013^{* *} & 14.3\end{array}$

